\title{
Dagligliv i Smedeby under 1. verdenskrig
}

af ARNOLD JOHANNSEN

Arnold Johannsen blev født i 1899 i Kruså. Han arbejdede under 1. verdenskrig på gårdejer Martin Møllers gård i Smedeby ved Kruså. I sine erindringer skildrer Arnold Johannsen hverdagslivet i landsbyen, langt fra storpolitikken og krigens slagmarker. Han fortæller om arbejdet på gården, forlystelseslivet, om stort og småt på sin egen lune måde. Erindringerne er nedskrevet sent, formentlig mellem 1978-1984. De udgør fortsættelsen til Arnold Johannsens erindringsbog fra 1978: Min barndoms Kruså 1900-1914. Arnold Johannsen døde i 1984.

Arbejdet herhjemme gik sin vante gang. Rugen var tjenlig, og vi begyndte at slå rundt om det store stykke rug, vi havde ude på Langageren. Men tankerne strejfede dog jævnligt bort til venner, der nu var ude ved fronten. Aviserne bragte hver dag sejrsmeldinger. Den ene store fæstning efter den anden faldt, og også mod syd gik det foreløbigt kun fremad. Christian Lenger, Klaus og Jes Asmussen var havnet på vestfronten, medens vejmand Hans Lambertsens søn, Theodor, var kommet til østfronten. I begyndelsen kom der tabslister med avisen. Dette varede dog kun nogle få dage. I den første tabsliste stod Theodor opført som falden. Min far og jeg havde truffet ham lige før jul på banegården i Flensborg, og jeg havde beundret ham meget, som den stoute husar han var. Det knirkede af læder, når han bevægede sig. $\mathrm{Og}$ nu var han altså allerede død og begravet. Det måtte vel være en kugle eller en granatsplint, der havde gjort ende på hans unge liv. For jeg kunne ikke forestille mig, at nogen kunne fælde ham i nærkamp.

Men som sagt, tabslisterne udkom kun et par dage, man har nok fundet, at det var for trist læsning. Aviserne fik dog også tid til at finde alle fremmedord frem, som nu skulle udryddes. Og der var efterhånden mange, mest franske. Man skulle ikke mere sige "adieu “ til afsked, men »auf Wiedersehen«. Herhjemme blev vi dog ved med at sige "adjes«. Det var noget, vi havde overtaget fra det plattyske 
"adjüs«, som dog oftest var amputeret til bare at hedde »tjys«, hvilket plattyskerne bruger den dag $\mathrm{i}$ dag. Vi blev også ved med at sige »adjes«, indtil vi efter Genforeningen langsomt gik over til »farvel«. Man kunne ikke mere købe en billet eller en returbillet, men skulle have et Fahrkarte eller Rückfahrkarte. En perron fandtes heller ikke mere, derimod en Bahnsteig. Og sådan var der mange andre ord. De fleste forsvandt da også for aldrig at komme igen.

Ude på hovedbanen skulle der de første par uger gås vagt om natten, og dertil blev gårdejerne med et vist hartkorn udkommanderet. Martin måtte også af sted. Han blev dog hurtigt ked af denne tjans og overtalte Peter, forkarlen, til at overtage den. Så kunne han senere altid få fri en dag derfor. Det kunne godt lade sig gøre at sende en stedfortræder. Kirketjener Hans Jensen fra Bov gik da også i stedet for en gårdejer. Engang da tiden blev ham for lang, lagde han sig til at sove ved siden af sporet. En ældre løjtnant gik inspektionstur langs strækningen, og da han fandt Hans, pirrede han til ham og spurgte, om det måske var ham, der holdt vagt her. Hans sprang op i retstilling og svarede prompte: "Jawohl, Herr Leutnant, fest steht und treu die Wacht am Rhein. "Løjtnanten tog det fra den gemytlige side, men mente dog, at Hans skulle forsege at holde sig på benene.

De første der blev berørt af den nye situation, var malkekøerne. De var vant til at få et fodertilskud af mask, som vi hver uge hentede et læs af i bryggeriet i Flensborg. Det var det pludselig forbi med, skønt de dog blev ved med at brygge øl, men det blev vel forbeholdt hestene i Flensborg. Så var der oliekager, dem var det også slut med. Avisen rådede til at gå over til fodersukker. Vi fik også et enkelt læs, men samtidig fik vi besked på, at mere kunne der ikke blive.

Nå, men køerne viste stor forståelse for situationen. Martin, der var i fuld gang med selvbinderen, blev pludselig nervøs for bindegarn. Han havde det sidste nøgle i maskinen. Så han stoppede op og kørte over til købmand P. Møller i Frøslev, hvor vi plejede at få det. Han fik da også den samme portion, som vi plejede at fă, men mere kunne der slet ikke blive tale om.

\section{Et regiment indkvarteres på gården}

Pludselig erklærede også England Tyskland krig, og dagen efter krigserklæringen kom der kvartermagere til byen. Vi skulle få indkvartering dagen derpå. Vi for vor part, hos Martin altså, skulle have 
Portret af Arnold Johannsen.

Fotografiet er formentlig taget umiddelbart efter krigen, hvor Arnold Johannsen er omkring $20 \mathrm{ar}$. Foto: Chr. Johannsen og Else Ebjerg.

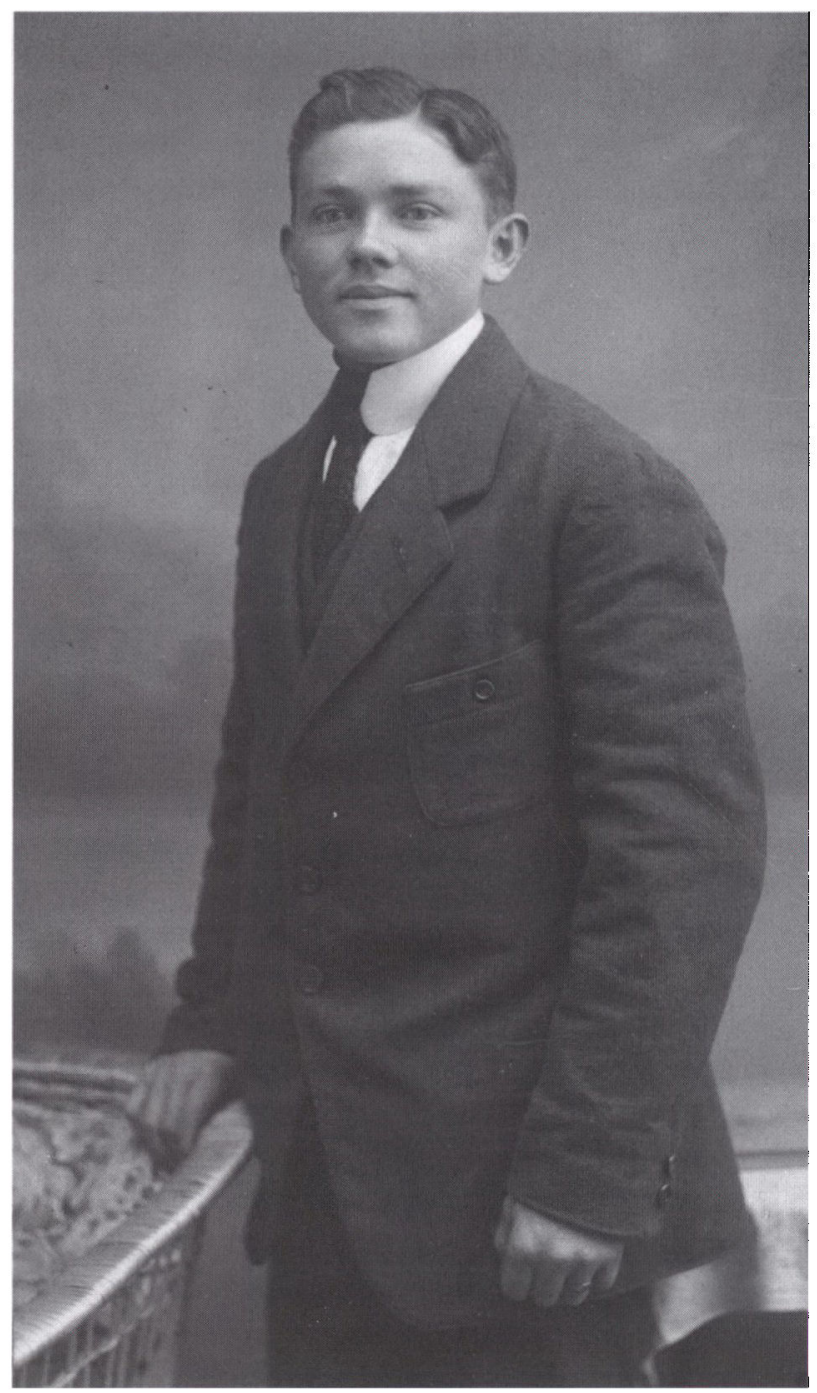

60 mand og to officerer. De skulle have middagsmad og aftensmad. Martin spændte straks for den lille fjedervogn og kørte ud til slagter Paulsen i Flensborg, hvor han købte ind i store portioner, for vi vidste ikke, hvor længe de blev. Han købte svinesteg, oksesteg og store mængder pålæg. Midde, husholdersken, fik besked på at bestille nogle koner til hjælp, og desuden indprentede han hende, at hun absolut 


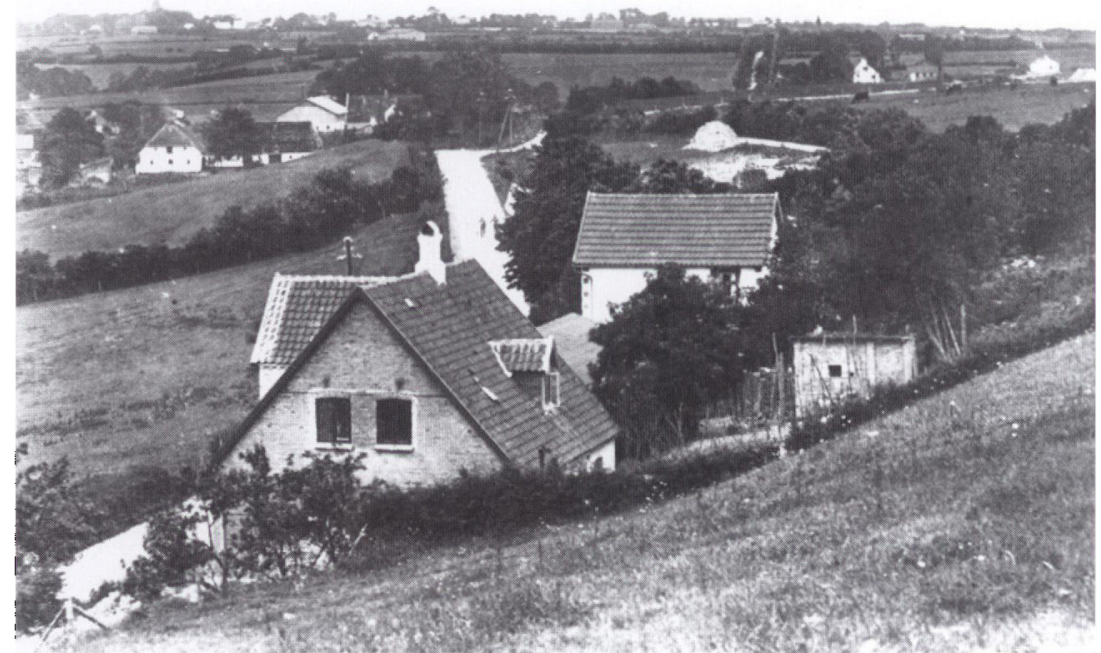

Smedeby set fra højen øst for byen. Det var over denne høj, soldaterne kom til indkvartering $i$ Smedeby. Martin Mallers ejendom ligger til venstre for vejen, henne $i$ svinget. Fotografiet er formentlig taget i 1920'erne. Foto: Bov Lokalarkiv.

ikke måtte spare på noget. Det var helt uvante toner for Midde. Hun levede næsten kun for at spare. Men hun lovede dog at følge hans ordre. Martin kørte så ud og mejede resten af rugen på Langageren. Nu skulle den bare skogges og stå et par dage, så var den tjenlig til at køres hjem. Næste formiddag gik med at opstille borde og siddepladser ude i loen til alle de folk. Ved hjælp af vognkasserne og alle brædder og planker vi kunne finde, fik vi også stablet det nødvendige spisemøblement sammen. De skulle komme om middagen, men både vi og køkkenpersonalet var rede til at modtage dem.

De kom så hen ad klokken et - et helt regiment. De var nyindkaldte, $\mathrm{i}$ de feltgrå uniformer. Det så næsten ud, som om der blev rullet et gråt kæmpetæppe ned ad højen øst for byen. Der var ingenting, der blinkede i det skarpe sollys. Nede $\mathrm{i}$ byen gjorde de holdt, og de blev tildelt deres kvarter med besked om, at de havde fri resten af dagen. Konerne fra køkkenet havde travlt med at dække bord. Spisevarerne forsvandt næsten som dug for solen, men noget levnedes dog. Mange af soldaterne hjalp til med at bære spisegrejet ind. Efter middagen strømmede de fleste af soldaterne ned $i$ den lille eng ved bækken for at vaske fødder, vaske deres fodlapper og halsbind. De 
lagde tingene i græsset og prøvede så at få en lille lur. De var trætte. Om morgenen var de afmarcheret fra Översee. Det var en betragtelig marchtur. De havde jo hele deres udrustning med, og efter hvad man sagde, vejede denne ca. 90 pund. Og solen sendte en voldsom varme ned over dem. Det var næsten udelukkende holstenere fra Regiment 163, som havde garnison i Rendsborg - eller måske var det Neumünster. Vi vidste ikke, hvad de skulle her - de heller ikke.

I første øjeblik tænkte man på, om krigen også skulle komme her, men man fejede hurtigt denne tanke bort. Danmark mobiliserede jo ikke, og de mange tog, der nu i en halv snes dage rullede herned med heste og andet gods, tydede da heller ikke på denne mulighed. For hvis Danmark ville føre krig, ville det vist ikke først sælge ud i et sådant omfang. I den danske rigsdag forhandlede man stadig, om man skulle afgive en neutralitetserklæring, og sandsynligvis ville Tyskland lægge pres på denne sag ved at sende styrker herop til grænsen. De greb også til andre forholdsregler. Alle fremtrædende folk inden for den danske bevægelse blev sat under husarrest på et hotel. Nå, de led igen savn der. Fra Bov Sogn var der ingen iblandt.

Hen imod aften blev soldaterne mere friske, og i små grupper gik de rundt og beså byen. De fandt den meget smuk og ideelt beliggende. De store grimme teglværker var på det tidspunkt jo forsvundet. Mest undrede de sig over, at de næsten ingen unge piger så i byen. Men dem var der på det tidspunkt også kun et par enkelte af i Smedeby. Soldaterne trøstede sig så med øl og sang. Det varede ikke længe, så havde marketenderen, der lå i Hokkerups gård, udsolgt. De fór over til Midde, købmanden i byen, men hun var jo ikke forberedt på et sådant run, så hendes lille lager af øl var forsvundet på få øjeblikke. Så var der kun kroen tilbage, men den lå alligevel for langt borte. Efterhånden blev det også tid til at tænke på aftensmaden, og de slentrede hen til deres kvarter. I loen opstabledes der bjerge af godt belagt brød, og konerne blev rost i høje toner. Men da de var færdige, var der ikke en krumme tilbage til stor forbavselse for køkkenfolkene. Det var nu slet ikke så underligt, for hvad der ikke blev spist, forsvandt ned i lommerne. Så havde de til deres morgenmad.

Martin var færdig med at høste rugen, og vi regnede med, at vi næste dag skulle ud og stille den op i skokker, men Martin sagde, at det behøvedes ikke. Det havde han allerede ordnet. Det var jo nu en umulighed, og vi stirrede lidt forbavset på ham og ventede egentlig en anden forklaring. Den kom også. Alle vore kvartergæ- 
ster var tidlig om morgenen rykket ud på Langageren og var i fuld gang med at skokke rugen. Med 60 mand ville de vist være færdig til middag. Det var de også, og det var en stor hjælp for os. Det er meget trættende hele dagen at slæbe negene sammen. Hen på formiddagen red både Oberstabsarzten og løjtnanten ud for at se på foretagendet. Jeg har vist fortalt, at vi havde to officerer i kvarter. De var indkvarteret $\mathrm{i}$ gæsteværelset og spiste sammen med Martin i hans lille privatstue. Oberstabsarzten hed Schumacher og var fra Broager. Løjtnanten var en Junker fra Mecklenburg. De var begge til hest, og deres heste stod i stalden, hvor deres oppassere også camperede i halmen, hvilket der lå en hel del af i stalden. Oberstabsarztens oppasser var fra Berlin og hed Paul. Ham hos løjtnanten var lige som sin herre en Mecklenburger, en stor langlemmet person, Franz. Paul viste os en ny revolver, som han havde købt sig i anledning af krigen. Han mente, den var god at have, hvis de kom $i$ trængsel med franskmændene, så kunne han hurtigt sætte fem-seks mand ud af spillet. Vi spurgte Franz, om han ikke havde en sådan. Men han mente, at han havde lange arme og et godt gevær, og kom nogen inden for hans rækkevidde, vendte han bare geværet om, og de ville falde til jorden og ikke rejse sig mere. Han så også sådan ud. Samme aften som vore soldater havde været på høstarbejde, kom regimentskapellet til Smedeby. De tog opstilling for enden af Christian Lengers gamle lade, og snart rullede de mægtige toner ned gennem dalene. De spillede afvekslende marcher, fædrelandssange og koraler. Et par af de sidste schlagere fra for krigen var også med på programmet, "Die Wacht am Rhein " også, og alle soldater sang med på dem. Man kunne ikke undgå at føle den voldsomme magt, disse toner udøvede, og føle den dybe alvor, man blev grebet af, da de sluttede med: »Ich habe mich ergeben«. Om aftenen samledes de atter i mindre klynger, nogle morede sig med soldaterløjer, andre sang soldaterviser. Der har vist aldrig været så meget liv og røre i Smedeby om aftenen som i de dage, de var der.

Men det tog også en ende. Danmark erklærede sig neutral, og næste morgen, da vi stod op, var de næsten sporløst forsvundet. Kun halmen $\mathrm{i}$ båsene $\mathrm{og}$ den interimistiske møblering $\mathrm{i}$ loen vidnede om, at de havde været her. I nattens løb var de draget til Fårhus, hvor der var en militærrampe, og hele styrken med heste, vogne og alt hvad der hørte til regimentet, var pakket $i$ et tog og sendt til Belgien. Et par dage senere kom der brev til flere af egnens beboere, de havde 
fået en meget uvenlig modtagelse i Belgien. I sluttet trop var de marcheret gennem en af byerne, da de pludselig blev beskudt fra alle vinduerne af civilbefolkningen. De havde haft svære tab, men de var straks brudt ind i husene, og enhver der var i besiddelse af et gevær, blev omgående skudt. Også den næste formiddag endnu blev der skudt flere fordægtige. Tyskerne gik meget hårdt frem mod disse franctireurs, sådan kaldte man dem dengang. $\mathrm{Og}$ det varede heller ikke længe, før disse snigmord hørte op.

Vi, det vil sige forkarlen Peter og jeg, havde i et anfald af storsind stillet vort kammer til rådighed for de fire underofficerer, der var blandt vore gæster. Vi selv sov ude i halmen i hestestalden, hvor de to oppassere også camperede. Nu tog vi det $\mathrm{i}$ besiddelse igen.

Efter soldaternes afrejse holdt hverdagen sit indtog igen. Den bragte arbejde nok. På grund af den vedblivende højsommer blev forårssæden faktisk moden, inden vi fik rugen ind, men Martin ville nu have rugen ind, inden han skulle give møde hos militæret. Det fik han også med nød og næppe, og et par dage senere drog Martin af sted. Hans rejse blev ikke så lang. Han blev indsat ved grænsebevogtningen oppe ved Kongeåen, hvor han tilsyneladende befandt sig meget vel. Han havde sluttet kammeratskab med Hans Peter Hansen, der var kromand i Nystaden i Flensborg. De to kendte jo hverandre, og de har sikkert rigtig givet rollen som et par djærve krigskarle deroppe.

\section{Hamstring og rationering}

Allerede ved krigens udbrud havde hamstrerne begyndt at røre på sig, men da der også blev krig med England og dernæst blokade for udenlandske varer, trådte de for alvor i aktion. Der blev hamstret alt i udenlandske kolonialvarer såsom kaffe, te, ris, kakao og mange andre ting, også stoffer i metervarer købte man op. Aviserne gik hårdt i rette med denne trafik og sidestillede hamstrerne med landets fjender, men lige meget hjalp det. Hamstrerne gav ikke op, før lagrene var tømte. Det var kun pengefolk, der havde råd til at hamstre. Småfolk havde her grund til at være forarget over denne egoistiske optræden. I Smedeby var der nærmest ingen hamstrere. Der var ikke mange, der var så velhavende, og desuden syntes de fleste, at det ikke havde nogen betydning, om de 14 dage frr eller senere måtte gå over til at drikke kornkaffe. 
Brød, smør og kødvarer blev rationeret, og til at begynde med var rationerne også til at leve med. Hos Martin var vi jo selvforsørgende, hvad brød og kød angik. Der blev ganske vist tildelt gården et vist parti brødkorn, som vi kunne få malet $i$ en vis periode, og vi kunne også slagte en gris om året, som der skulle holdes hus med i en bestemt periode. Men smørkort, dem var vi jo nødt til at have. Smør var dog en udmærket vare at holde hus med. Man kunne blande det med $75 \%$ kartofler, og det smagte stadig lidt af smør.

Der kom også mange slags erstatninger frem. Mange af dem kunne godt bruges, om end ikke til det de var beregnet til, så til noget andet. Hvis man stuvede en pande kartofler i skummet mælk og så strøede en håndfuld kaffeerstatning over den, blev de brune, som om de var stegt $\mathrm{i}$ fedt eller margarine, og de fik også en anden lidt mere pikant smag. Der fandtes også en slags pålæg i tuber. Den var udmærket til at pudse skotøj med, og sådan var der flere, man skulle bare selv finde ud af, hvad de egnede sig til.

Livet gik egentlig nogenlunde som før krigen. Arbejdet var jo det samme. Ganske vist måtte man undvære snart det ene og snart det andet, men det kom jo sådan pø om pø, så man havde tid til at vænne sig til det. De første vanskeligheder meldte sig egentlig med festtøjet. Man kunne ikke mere få stovlerne forsålet, kun når man selv medbragte sålelæder, men det var næsten umuligt at skaffe. Var man heldig, kunne man få fat i et stykke gammelt drivrem. Så blev støvlerne forsålet, hælen forsynet med jernring og sålerne spækket med soldatersøm, så de kunne holde længe. Sæben var også knap. For toiletsæbe fik man en erstatning. Det var nærmest en lerklump, der lugtede lidt af sæbe, og de første otte dage kunne man også få den til at skumme lidt, men så var det også forbi.

Til gengæld for alle disse små genvordigheder havde man ingen pengesorger mere. Varerne, de par som man fik tildelt, steg ikke, og udgifterne til dem blev jo efterhånden stærkt begrænset. Soldaterkonerne fik en forholdsvis god understøttelse. Denne blev i øvrigt udbetalt hos kommuneforstanderen Jørgen Lenger, som også stod for tildelingen af rationeringskort. Rusen, som havde grebet folk i begyndelsen, var for længst borte og havde givet plads for en nøgtern overvejelse. Man regnede med, at krigen ville vare årevis endnu, og man var ikke mere så sikker på, hvem der ville sejre. Der meldte sig jo stadig nye fjender fra fjerne egne. 


\section{Forlystelseslivet}

Ude på Bezirkskommandoen havde de stadig travlt, og der gik hver dag en strøm fra omegnen til Flensborg. Der var mange gamle bekendte, der mødtes der, og efter at have fået deres papirer $\mathrm{i}$ orden, mødtes de gerne $i$ en af de talrige kroer for at fejre begivenheden ved en lille kaffepunch. Det blev jo oftest til en hel række, og om aftenen drog de så i skarer, syngende og skrålende, ned til de sidste tog. Der var borgere, der besværede sig over denne uro om natten. Byrådet lagde hovedet $\mathrm{i}$ blød og fik så en lys, men dog lidt besynderlig idé. Det var jo kaffepunchene, der var skyld i disse uroligheder. En punch kostede 15 Pf. eller syv for én Mark.

Man sendte så en forordning ud til gæstgiverne $\mathrm{i}$ byen, at fremtidig måtte de kun udskænke kaffepunch til 50 Pf. pr. stk. Selvfølgelig skulle de beholde samme sammensætning som før, de måtte bare ikke mere udskænkes i små portioner. Gæsterne studsede jo lidt ved denne forordning, men de fandt hurtigt på råd. Når der nu kom tre eller fire mand ind for at fejre gensynet, bestilte de bare en punch eller tre eller fire kopper, alt efter hvor mange de var, og forordningen havde ingen som helst virkning. Den havde bare givet værtshusene en udgift til de store kopper. Det varede da heller ikke længe, før alt var ved det gamle. Om forordningen så blev ophævet, eller om den bare gik i glemsel, kan jeg ikke sige, men den havde unægtelig vakt megen forundring.

Al dans og forlystelse var jo forbudt, så de unge havde næsten ingen andre fornøjelser end dem, de selv skabte sig. Cykelture var det for længst forbi med. Straks i begyndelsen af krigen skulle alt cykelgummi afleveres, og cyklerne lå nu på loftet eller i udhuset og rustede. Alt messing- og kobbertøj skulle i øvrigt også afleveres. Der var et par tilløb til at lave erstatninger for cykelgummi, men de viste sig at være ubrugelige.

Der var dog en gang imellem et enkelt lyspunkt. Således var der i Flensborg en stor omfangsrig krigsudstilling. Der så man legemsstore figurer af alle fjendtlige soldater $i$ deres originale uniformer og med hele deres udrustning. Der var hvide, sorte, brune og gule folk fra alle verdens lande. Der var mange forskellige erobrede våben, skyts og andet krigsmateriel, et par erobrede fjendtlige flyvemaskiner og meget andet, men det var meget interessant.

Et andet lyspunkt, langt mere behageligt, var, når der kom en kar- 
rusel til Flensborg. Den opstilledes i Nystaden, lige over for Biehls Trælasthandel, hvor der dengang var en stor ubebygget plads. Skønt der ikke var andet end den ene karrusel, var der sort af mennesker, og folk, som var kommet for at køre karrusel, måtte vente til klokken $9.30 \mathrm{om}$ aftenen, for da forsvandt soldaterne og en hel del piger. Soldaterne skulle jo være i seng klokken ti. Men det var heller ikke for at køre karrusel, de fleste var kommet. Karrusellen spillede jo alle kendte dansemelodier fra før, og også nogle nye, og rundt om på den store plads så man par, der dansede på den jævne hårde jordbund. De dansede ikke runddans som for alt foregik i en slags onestep, der bestod i snart at tage nogle skridt forlæns, så at lave en vending og gå baglæns, ind imellem nogle sving til siden og en hel del andre figurer, alt efter smag og behag. Politi var der vidt og bredt ikke at se. Vi vovede os også ud i tummelen, og skønt vi ikke kunne hamle op med byboerne, morede vi os noget så fortræffeligt. Men man skulle være yderst forsigtig, så man ikke kom til at træde den udkårne på tæerne med de jernbeslåede snørestøvler. Vi var i højt humør, da det kl. ti var slut, skønt vi slet ikke havde nået at køre karrusel. I en stor flok drev vi ud til nordenden af byen. Mange bøjede jo af undervejs, og til sidst var vi alene med »Klueserne«. Pigerne fra Klues var meget frække. De hev os ud og prøvede at bibringe os de rigtige dansetrin. De opgav dog hurtigt, vi var for træbenede, sagde de. De opfordrede os til at komme til Klues en gang imellem, der havde de et sted, hvor de ofte dansede om aftenen i mørke, endog med klavermusik. Vi levede længe højt på sådan en tur, men som sagt, det var meget sjældent, en sådan begivenhed fandt sted. Det var vist ikke en gang hvert år.

I mørketiden sad vi meget om aftenen på nogle halmknipper i vores hestestald. Der var lunt, og vi sad og udvekslede nyheder, sang og spillede lidt, og en enkelt gang prøvede vi også nogle dansetrin. En gang imellem gik vi til Kino i Flensborg. Det kunne også godt være lidt opløftende. Skønt det ikke kostede ret meget med toget til Flensborg, gik vi alle i flok ind til byen. Måske fordi vi havde det mere fornøjeligt og afvekslende. Vi gik i det hele taget meget. Var der én der havde et ærinde i en af nabobyerne, gik vi hele flokken med, og vi morede os undervejs med mundharmonika og skæmt.

Om efteråret rejste Peter, forkarlen, og så kom Ole Hokkerup. Han havde været forkarl på gården, da jeg endnu gik i skole og var dreng der. Nu trådte han til som bestyrer og tog Martins lille private stue i 
besiddelse. Jeg var meget glad for Ole. Han var altid i godt humor, og det var dejligt at arbejde sammen med ham. Han var 18 år, men trods sin unge alder var han en meget dygtig landmand, der sikkert ville have fået meget mere ud af gården end Martin, hvis han havde siddet der. Men som sagt: Ole var 18 år, og om efteråret var han til session og blev udtaget til feltartilleriet. Han var ikke særlig glad for at blive soldat, men glædede sig dog over, at han skulle være artillerist og beholde sin omgang med heste. Med sit kendskab til heste var han ikke i tvivl om, at han ville blive tildelt bespændingen - og sådan gik det også. Som sagt: Ole sang hele dagen. Han havde en høj klar stemme, men kunne desværre ikke rigtig holde tonen og blev også ofte gjort opmærksom derpå, men det generede ikke Ole. Han sang bare videre af hjertens lyst. Han havde to yndlingsviser, det var den om Skamlingsbanken og "Jeg er en simpel bondemand «. Men efter at være udtaget til artilleriet udvidede han dog programmet med en tysk sang. Det var den om det store vældige folk, der kaldte sig artillerister. Ole blev kaldt ind til foråret. Alt forefaldende arbejde var da udført, og han efterlod gården i en fin stand.

Vi fik en ny forkarl. Det var Christian Petersen, søn af kromanden i Kruså. Samtidig fik vi også en bestyrer. Det var onkel Hans Peter. Hans Peter var meget tunghør. Han havde aldeles ingen autoritære ambitioner, og driften foregik i meget demokratisk stil. Men vi var jo fuldt besat igen, hvad mandskab angik. Hvad heste angik, så det ikke så godt ud. Vore to bedste heste havde militæret taget, og vi havde nu kun de tre helt unge to års og så vores følhoppe Lise. Lise var allerede 20 år og blev egentlig sat på pension lige før krigen, men nu måtte hun altså igen træde an, hvad hun slet ikke syntes om. Hun kunne jo ikke slå mere, men hun havde lange tænder, og når man intetanende gik forbi på siden af hende, kunne hun godt finde på at bide en i armen, ikke særlig hårdt, men det kunne godt gøre ondt.

\section{Krigsfanger i landbruget}

Hen i maj måned fik vi krigsfanger til hjælp ved landbruget. I Bov var der indrettet kvarter for dem, og der fulgte to vagtposter med til at holde tilsyn med dem. Det var englændere, der kom. Det var man egentlig ikke så glad for, man havde hellere haft russere. Ham vi fik, hed Jack Riggestaf og var fra Blackpool. De fleste af dem var folk tæt op imod de 40 år. De kom lige til middag, og da vi havde spist og 


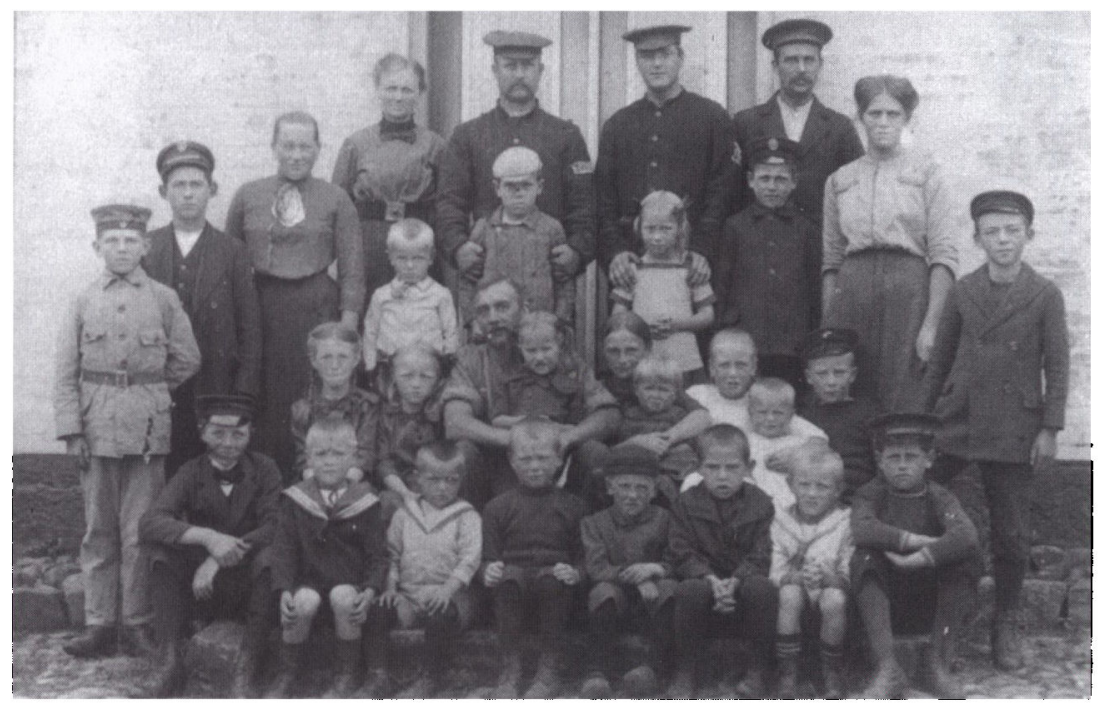

To engelske krigsfanger sammen med en flok børn fra Smedeby. Krigsfangerne bagest $i$ midten. Arnold Johannsen står yderst til venstre $i$ billedet. Arnolds bror, Kedde, har kasket på og står lige foran den ene krigsfange. 1914. Foto: Bov Lokalarkiv.

kom ud i stalden, trak Jack sin kridtpibe frem og viste os, at han gerne ville have lidt tobak. Han havde også en håndfuld tyske småpenge, som han åbenbart ville betale med. Hans Peter søgte en ti-penning ud og betydede ham, at han skulle gå ned til Midde og vise hende den og den tomme pibe og bare sige: "Tobak".

Jack gik derned og kom glædesstrålende tilbage med et kræmmerhus fyldt med tobak. Han fortalte en hel masse, som vi dog ikke forstod. Formentlig var han forundret over, at han kunne bevæge sig frit omkring og endog gå ind og handle i forretningen. I øvrigt viste bøndernes mistro over for englænderne sig at være berettiget. De havde, for de flestes vedkommende, slet ingen anelse om landbrug og var i så henseende ikke til megen nytte. Jack heller ikke. Han fór altid travlt omkring, men hans indsats var tit planløs og ikke til nogen rigtig nytte. Men til trods derfor, var vi egentlig glade for ham. Han havde et aldrig svigtende humør, og senere, da vi kunne gøre os forståelige med hinanden, havde han altid mange pudsige indfald.

$\mathrm{Da}$ de havde været her et stykke tid, begyndte der at strømme pakker ind til dem. Der var alle mulige varer, som vi slet ikke engang drømte om. Der var rosinbrød i lange baner, chokolade både til at smøre og i plader, marmelade, te, tobak, cigaretter og mange andre 
ting, strømper og undertøj til at imødegå vinteren og skotøj. Af mange ting havde de en sand overflod. Det var nu ikke sådan, at de lod folk her få del i den. Det kunne ske, at man kunne købe noget undertøj eller et par sokker for god betaling, men det var meget sjældent. Fangerne kunne åbenbart ikke tåle denne overflod. De tog sig utallige friheder, og når det ikke passede dem, meldte de sig syge og ville ikke arbejde.

Vagtmændene kunne ikke stille noget op med dem. De har sikkert været bestukket. Der kom klager ind til fangetilsynet, og kort før jul blev vagtmændene afløst af Martin, der kom fra Belgien, og Christian Jørgensen, en gårdejer fra Bov. Nu skulle der skabes ordentlige tilstande igen. Fangerne gik dog ikke med dertil. De var stadig mest syge, når de skulle på arbejde. En af dem, som Martin ville jage op på arbejde, påstod, at Martin havde slået ham, og hele flokken besluttede straks næste dag at strejke. Vagtmændene måtte have bud efter deres foresatte, og de kom også omgående. Fangerne provede at forhandle og anførte forskellige grunde, men chefen afviste pure at forhandle med krigsfanger. Han erklærede rent ud, at han nu var kommet for at sende dem tilbage til fangelejren i Güstrov igen. Det havde fangerne vel ikke ventet. Men der var intet at gøre. Jack kom om aftenen ned og fortalte mig det. Han havde et sæt civilt tøj hængende i mit klædeskab, og det ville han nu gerne have med. Han fik sit tøj og tog afsked. Han var oprigtig ked af det - det var jeg også, men det lod sig jo ikke ændre. To dage senere kom der russere i stedet. Det var helt andre folk, og de blev efterhånden højt værdsat af deres arbejdsgivere, der $\mathrm{i}$ dem havde en trofast hjælp gennem de sidste år af krigen.

\section{Flere indkaldes til militærtjeneste}

Men tilbage til gården. Det blev forår og høhøsten begyndte så småt. Høhøsten var det mest arbejdsberøvende foretagende på gården. Kvantummæssigt havde vi lige så meget hø som korn på gården, men det fordrede en meget større indsats. Alt græs i de mange enge skulle slås med le, og når vi endelig havde det tørt, skulle hovedparten bæres op til fast grund. Også selve hjemkørslen og henpakningen var meget mere besværlig end med korn. Men vi nåede det. Vi var næsten ved at være færdige, da Hans Peter igen skulle til undersøgelse, og denne gang havde de brug for ham. Han hjalp os så endnu et par 


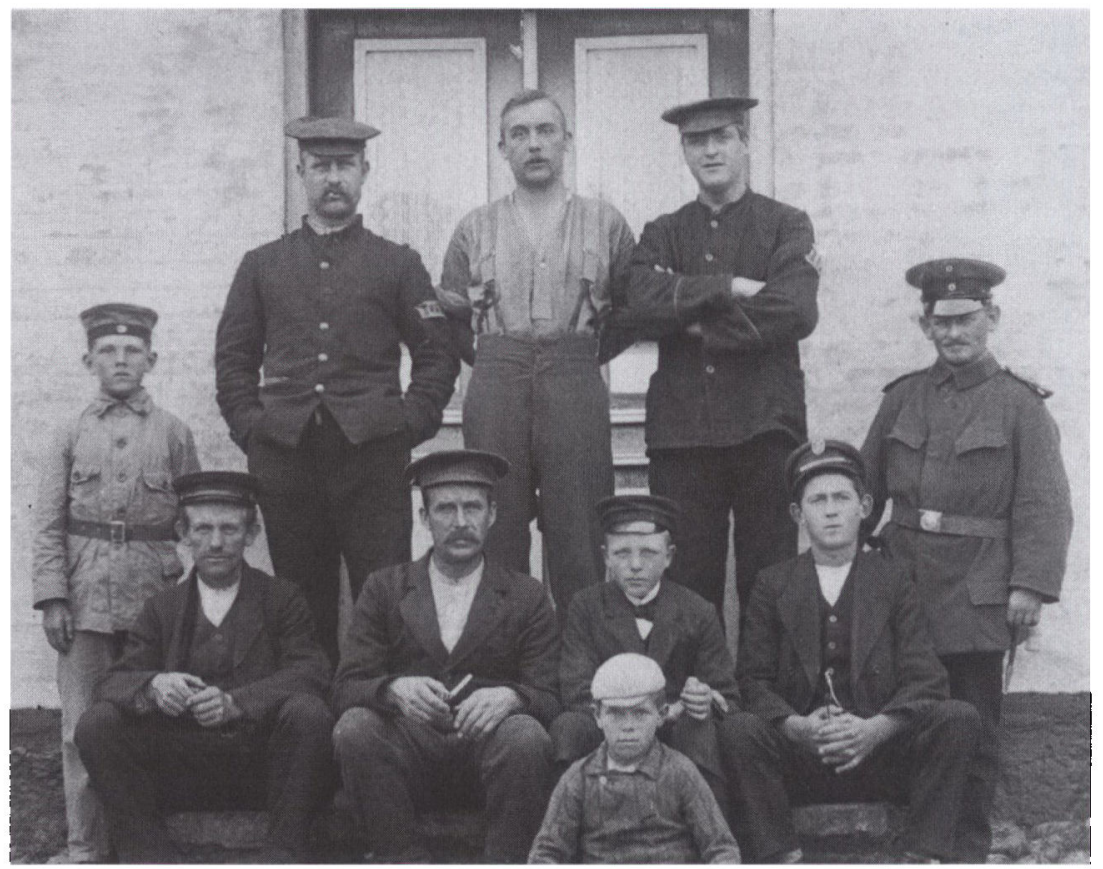

Fotografiet er fra 1914 og viser formentlig mandskabet på Martins gd̊rd med Martin bagest $i$ midten. Det er med sikkerhed Arnold $i$ sin Jugenduniform langst til venstre, og nederst ses Arnolds bror, Kedde. Arnold sendte $i 1915$ fotografiet som feltpost til sin far, der var på uddannelse $i$ Königsberg. Foto: Chr. Johannsen og Else Ebjerg.

dage, indtil den røde seddel kom. Så holdt han op. De sidste par dage ville han ordne sine sager i hjemmet. Vi var mere end kede af, at han forlod os. Vi havde haft et så godt samarbejde på gården.

Onkel Hans Peter og Jacob blev indkaldt et par dage senere. De var tvillinger og havde altid holdt sammen. For det meste havde de også arbejdet sammen. De kom begge til Rendsborg, og efter endt uddannelse blev de begge anbragt $i$ et stort skomagerværksted for militærfodtøj, hvor de blev tillært. Godt et kvart år senere blev de dog revet så vidt fra hinanden, som det næsten var muligt. Jackob kom til Rusland, og Hans Peter sendte de til Frankrig. Min far var allerede indkaldt til jul 1914. Han blev uddannet i Königsberg, og kom derefter på vagt ved den russiske grænse. De havde en hytte inde midt $\mathrm{i}$ den store skov, hvor de selv camperede med madlavning. Hele ugen så de ikke et menneske, undtagen når underofficeren kom med post. Det var vældige områder, de havde tilplantet med nåleskov 
i Østpreussen, skrev min far. Man kunne marchere en hel dag igennem de store skove uden at komme ud af dem.

Vi skulle jo igen i gang med høsten. Denne gang uden soldater. Vi fik dog lov til at låne Thomas' aflægger. Hele højen blev afhøstet. Det skulle jo alt sammen bindes med hånd og strå nu, og vi måtte alle træde til. Både Guste og Midde hjalp til. Jack fik også lært kunsten, og han viste sig også virkelig at være en god hjælp i mange henseender. Han begyndte efterhånden at gribe arbejdet mere fornuftigt an. Min bror Kedde, der endnu gik i skole, men var i tjeneste på gården, måtte også hjælpe til i sin fritid. I det hele taget gik vi på arbejdet med krum hals. Vejret var lidt mere ustadigt end den foregående sommer, men med forenede kræfter bragte vi høsten $i$ hus inden udgangen af september, og det var godt præsteret.

Det syntes vi selv, og vi fejrede derfor en slags høstfest ved at få vafler og sødsuppe til middag. Mel til vaflerne snød Midde grisene for. Hun sigtede det fine mel, som grisene skulle have. De fik så kartofler i stedet, når de gjorde vrøvl. Melet blev æltet, og der kom lidt sødestof i. Det brugtes i stedet for sukker, og det var da også meget brugeligt. Hun havde et vaffeljern, der var formet som en klemme, men på enden var der altså to firkantede flader med en form i til vaflerne. Disse forme blev gnedet over med flæskesvær, dejen blev hældt $i$, tangen klappet til og holdt over ilden et øjeblik, og vaflen var færdig. Et par minutter holdt den sig fast og sprød, så blev den slatten, men derfor smagte den godt alligevel. Det blev et festmåltid, som vi huskede længe.

Til jul kom Martin hjem som vagtmand, og vi fik skiftet Jack ud med en russer, men det har jeg foran berettet om. Russeren Mitri var jo fra landet, og intet arbejde var ham fremmed. Med ham havde vi fået en uvurderlig medhjælper. Også Martin havde jo nu taget hånd $\mathrm{i}$ hanke med arbejdet på gården. Han overtog arbejdet $\mathrm{i}$ stalden og hvad der ellers var på gården. Han skulle jo være der, når der kom inspektion. Han vovede sig dog også ved enkelte lejligheder ud i marken, men så skulle han have geværet med. Vi var i det hele taget godt besat med mandskab nu.

1916 begyndte med store snemasser. Alle veje var tilføget, og vi måtte i flere uger stille en mand til at rydde sne væk. Men også bagefter var de store snemasser til megen besvær. Efterhånden kom der flere og flere vanskeligheder. Der var megen besvær med belysningen ved arbejdet i stalden og på loftet. Petroleum var der ikke meget af. 
Man kunne få staldlygter til karbid og også til kogesprit. Men karbidlamperne var hvert øjeblik stoppet. Og spritlamperne, de havde et ualmindeligt klart lys. De havde altså nogen med en slags strømpe, kaldte vi det. Det var den, der lyste, men den var så ømtålelig, at den sank sammen, bare man sagde et kraftigt ord, og så var det forbi med lyset. Det meste af arbejdet måtte vi forrette i mørke. Man indførte sommertid. Det hjalp en del om aftenen, men til gengæld var det jo længere mørkt om morgenen. At få solen til at forandre køreplanen viste sig at være umuligt.

\section{Lappede støvler og bukser af papir}

Men også andre ting begyndte det at knibe alvorligt med. Skotøj havde det allerede længe været vanskeligt med, men nu kneb det også med arbejdstøj. Jeg købte et par bukser i Flensborg hos Adolf Johansen $\mathrm{i}$ Nørregade. De var udstillet i vinduet og kostede ikke ret meget. Man gjorde mig dog opmærksom på, at de egentlig var tiltænkt til indendørsbrug, da de ikke tålte at blive våde. De var fremstillet af grove papirtrævler, som var sammenvævet, og når de bare ikke blev våde, kunne de holde længe. Selvfølgelig kunne de heller ikke vaskes. Det var altså så at sige engangsbukser. De følte sig meget slidstærke an, og da prisen var meget lav, købte jeg et par.

Hjemme trak jeg dem på og bragte mine to par gamle bukser op til mor, som havde lovet at flikke dem sammen. Mor så forundret på mine nye bukser og følte på stoffet. »Men det er jo kun papir«, udbrød hun. "Kunne du ikke se det? « Jo, det vidste jeg nok, men jeg sagde hende, hvad man havde fortalt mig og mente, at en vis tid kunne de vel nok holde. Hun lovede at flikke mine de gamle sammen, for det ville nok ikke vare længe, for jeg fik brug for dem. Og jeg kunne se, at hun slet ikke var tilfreds med min handel. Vejret var nogenlunde stabilt de følgende dage, og jeg vovede at tage papirbukserne på ud i marken. Det gik da også godt i nogle dage. Men så en dag kom der en lille byge, da jeg red fra marken, og det var nok til, at jeg kunne mærke, at mine fine nye bukser blev våde. Da jeg kom hjem, skyndte jeg mig at trække dem af og byttede med Jugendwehrbukserne. Papirbukserne hængte jeg forsigtigt op på stalddøren, hvor de havde chance for at torre lidt. Men næste morgen lå det ene bukseben nedenfor stalddøren. Så var den drøm ude.

Hen på efteråret blev der dog en lille lysning angående støvler og 
arbejdstøj. Der oprettedes to udsalgssteder i Flensborg: et for brugte, reparerede militærstøvler, og et for arbejdstrøjer og bukser omsyet til civilt formål af kasseret militærudstyr. De lå begge nede ved havnen. Men man skulle være i besiddelse af en Bezugschein, der viste, at man var trængende. Straks om aftenen gik jeg op til sadelmager Ulrich i Bov og fik også papirer på både støvler, jakke og bukser. Næste dag gik jeg så til Flensborg. Støvlelageret fandt jeg straks. Det lå et par huse syd for Skibbrogade, oppe på første sal. Der var to rum, et mindre foran, hvor der lå en del støvler på gulvet, og et større bagved, hvor lageret var, og hvor der sad to soldater. Jeg afleverede mit bevis til støvler, og den ene sagde, jeg kunne gå ud i det første rum og finde et par. Der lå, som sagt, ikke mange støvler der, og en ældre mand gik småbandende og sparkede rundt i dem. Én støvle havde han på armen, det var den højre, sagde han, men han kunne ikke finde den passende venstre. Det var næsten alle højre, hvad der var tilbage. Jeg fandt også en højre, som jeg syntes godt om, men en venstre i samme størrelse var der åbenbart ikke. "Om vi så bliver her hele dagen, bliver disse støvler ikke venstre«, mente han og gik hen og bankede på døren til lageret. "Hvad sker der? « kom den ene af de to soldater straks farende. "Vi skal have flere støvler herud, der er jo kun højre tilbage«, sagde manden. Soldaten greb en gammeldags tørvegreb, dem med træzinker, og hentede et par forkefulde ud til os. Jeg så straks, at på den ene af dem var sålen revet af og viste den ældre mand den. "Det var dog besynderligt«, mente han. »Det må vi have en forklaring på«. Han bankede på døren igen. Den fløj straks op. "Hvad er der nu? « næsten brølede soldaten. "Ja«, sagde manden, "denne her «, han holdt støvlen med den afrevne sål $i$ hånden, "bragte De lige ind, og jeg kan ikke forstå, at De sidder der på værkstedet og reparerer dem og forsåler dem og så river sålen af igen, når de bliver sendt ud. Kan De forklare mig det?«, »Det er én af kunderne, der har revet den af, " mente soldaten. Men det benægtede vi, der var jo ingen andre end vi to, og vi havde begge set, at den lige var hentet ind fra lageret. Den anden mand sagde, at han bestemt troede, at sålen lå et eller andet sted derinde. "Hvad mener du med det?«. "Jo«, sagde manden. "Jeg tror bestemt, sålen ligger et eller andet sted derinde, jeg har fået sådan en grim mistanke om, at den er kommet til skade inde hos jer. Men hvis I lader os komme derind og finde, hvad vi mangler, vil jeg hurtigt glemme mistanken. I modsat fald vil vi søge at få en forklaring på højere sted.« Soldaten slog døren i for at snakke 


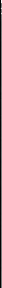

Smedeby. Ca. 1930. Foto: Bov Lokalarkiv. 1. Jørgen Lengers gård. 2. Chr. Lengers gård. 3. Hokkerups gård (eksisterer ikke mere). 4. Martin Mollers gård. 5. "Slottet «. 6. Middes kobmandshandel. Martin Moller solgte gården $i 1936$ til Jes Juhler, som solgte den $i 1946$ til Magnus Vest Hansen, nuværende ejer.

med sin kollega. Men efter en kort pause lukkede han op igen, viste hen på den store bunke og sagde: "Find så hvad I mangler, men hurtigt, det er straks middag." Vi var hurtige i vendingen. Jeg fandt et par støvler, som var sammenbundne, men de syntes mig at være $i$ meget god stand, så jeg lod den første, jeg havde fundet, ligge og bestemte mig for de to. Min medkunde fandt da også en venstre støvle. Vi betalte, skrev under på en liste og forsvandt. Soldaterne så meget sure $u d$, og for at trøste dem lidt sagde min kammerat: "Lad nu dette være jer en lære - så er jeg tilfreds." Jeg tog afsked med ham udenfor, og sagde til ham, at jeg var meget glad for at have truffet ham, thi, om end jeg godt indså soldaternes bedrageri, havde jeg ikke været fræk nok til at sætte dem på plads.

Lageret, hvor jeg skulle have arbejdstøj, var også lukket til klokken et, så jeg gik i mellemtiden en tur op til marskandiserne i Mariegade. Men der var nu ikke noget, der interesserede mig videre. Det var jo også begrænset, hvor mange penge jeg havde med. Klokken et måtte jeg så til det omtalte tøjdepot. Der så nu mere forretningsmæssigt ud end i støvledepotet. Der var brede hylder, hvorpå der lå masser af bukser og jakker, alt sammen af brugte militæruniformer. Det meste 
endog af de gamle blå uniformer. Over hver bunke stod, skrevet med kridt, et nummer, sandsynligvis for nogenlunde at angive størrelsen. Der var en venlig ung soldat, sandsynligvis en krigsinvalid, for han haltede på det ene ben. Han fik min seddel og smed straks et par bukser hen på bordet foran mig. "De passer", sagde han. Det var brune manchesterbukser, i dag kalder man dem fløjlsbukser.

Jeg prøvede at række dem ud med armene - de skulle nok passe. De var vist kortet lidt op, kunne jeg se på sømmene på ben-enderne, men ellers så de slet ikke ud til at have lidt overlast. Jakken fandt han også hurtigt frem. Den var af blå uniformsstof, men den var sammensyet af nogle enkelte store stykker og så en hel mængde mindre stykker. Det var de alle, forklarede han mig, og det så de også ud til at være. Jeg måtte gerne prøve den. Det gjorde jeg, og den passede meget godt og følte sig lun og varm an. Jeg besluttede mig for de to dele, pakkede det hele sammen i min rygsæk, takkede ham for den venlige behandling og glemte heller ikke at betale og kvittere for modtagelse af tøjet. Jeg var meget godt tilfreds med min handel og begav mig muntert på vej hjemad. Jeg længtes efter at gøre mor delagtig i min glæde. Mor var meget godt tilfreds med mine indkøb. Hun glædede sig næsten mere end jeg. Jeg kunne nu se vinteren $i$ møde med en vis sindsro.

Soldaterkonerne gik af og til, tre til fire ad gangen, til Flensborg og hjemsøgte marskandiserne. Et stykke strikketøj kunne oprimpes og garnet bruges til at strikke strømper af. Gamle frakker og jakker kunne sprættes op, vendes og syes børnetøj af. Intet undgik soldaterkonernes skarpe øjne. Også brugbart børnefodtøj kunne de undertiden støde på. Når de havde afgræsset marskandiserne, gik de ned og kørte med toget hjem. Udbyttet var ikke altid tilfredsstillende, men de havde haft en fornøjelig eftermiddag.

\section{Lyngkoste}

Jes Asmussen blev hjemsendt det år. Han havde været hårdt såret. En granatsplint havde ramt ham $\mathrm{i}$ hovedet og beskadiget hjerneskallen. I lang tid lå han på lazaret, men nu havde de altså fået ham på benene igen. Han var faldet en del af og var endnu sløj efter det lange lazaretophold. Men ellers var han den gamle igen. Han kunne dog foreløbig ikke optage sit gamle arbejde. I stedet for det manglende stykke af hjerneskallen havde de indsat en sølvplade, men den generede ham 
ikke. Dora, hans kone, var ovenud lykkelig. Hun havde Jes hjemme igen, og han skulle aldrig mere i krig. Tiden blev dog Jes for lang, og han begyndte at lave lyngkoste. Der var en lille fabrik ude i Fårhus, som havde optaget denne industri. Af dem fik Jes de nodvendige træstykker, og de færdige koste aftog de også. Fiskebenskoste gaves der jo for længst ikke mere. Så prøvede man med lyng. De bestod af to stykker træ, foroven trekvart tomme tyk og forneden en tomme, de var tre tommer brede, og på indersiden var der riller, ca. en $\mathrm{cm}$ tyk og bred. I disse riller lagde man så små lyngduske. De to træstykker blev fast sammenpresset, formedelst to bolte. I midten af de to træstykker var der et hul til skaftet. Kosten blev forneden lidt afpudset og var nu egentlig færdig. De små lyngduske blev mest lavet som hjemmearbejde i akkord. Mitri, vor fange, og jeg begyndte også at lave dem for Jes. Det skulle være ung lyng, og vi hentede hver en sækfuld ude i Asmus Jessens mose. Vi indså dog ret hurtigt, at de penge, der var at hente der, var alt for små, og gav så op. Jes var heller ikke lang tid i den branche og holdt også op. Jeg har aldrig prøvet disse koste, for vi brugte de gammeldags riskoste. Men jeg kan tænke mig, at de kun havde ret kort levetid. Men de havde jo den fordel, at hvis lyngdusken var opslidt, kunne man bare sætte nye ind. Men i Smedeby fandt de nu ikke nogen fremtid.

\section{Frosne kartofler}

Da julen var overstået, havde vi ingen spisekartofler mere. Det vil sige, vi havde dem nok, men de var nedkulet sammen med læggekartoflerne. Vi gravede os ned til dem, og så viste det sig, at hele dyngen var frosset. Det var nærmest en katastrofe. Men Martin så lyst på sagen. Til foråret ville vi nok kunne få læggekartofler udleveret, og vi havde masser af gulerødder, som vi måtte vænne os til at spise $i$ stedet for kartofler. Det med gulerødderne var rigtig nok. Dem havde vi et godt forråd af. Men disse store gule tingester var egentlig beregnet til hestene. Vi gav os allerede næste dag i kast med dem. Det skulle blive til mange dage, inden vi igen så kartofler. Efter et par dages forløb var vi så lede og kede af dem, at vi helst havde smidt dem bort. Og det blev værre og værre. Så vi længtes næsten mere efter kartofler end efter freden. Martin sagde, at der var ingen at få, men jeg tror ikke, at han har gjort sig megen ulejlighed $\mathrm{i}$ den sag. Måske kunne han godt lide gulerødder, men det så det nu ikke ud til 
ved bordet. Kartofler var ellers ingen særlig mangelvare, men vi fik altså ingen. Hver middag måtte vi sidde og gnaske disse gule krabater i os med megen ubehag. Jeg var sommetider ved at få kvalme derved, og den obligate rugvælling var ligefrem en delikatesse i sammenligning med dem. Rugvælling var i øvrigt vor hovedernæring. Den fik vi både morgen og aften. Om morgenen med to stykker brød til. Og om aftenen kun ét stykke, for det meste med kvark på. Kvark var en slags ost, som man lavede af skummetmælk, og den lod sig smøre lige som smør. Vel skulle vi aflevere alt korn, men vi beholdt dog sædekornet tilbage, og det plejede ikke at være så strengt udregnet, at der ikke blev noget tilovers til privat brug. Piger tilbragte megen tid med at dreje på kaffemøllen - rug til at brænde kaffe af og rug til vælling. Men tilbage til de frosne kartofler: Martin mente, når de blev kogt, ville svinene nok æde dem. De blev så renset, og så sad kvindfolkene i mange dage og rev dem på et lille køkkenrivejern. Derpå blev den våde masse tørret i komfuret. Og da de var færdige, var der vist ingen $i$ hele omegnen, der havde så meget kartoffelmel som vi. Vi fik i øvrigt ingen læggekartofler før i juni måned. Det var jo sent, men vi havde aldrig haft kartofler, der gav så stort udbytte, som disse. Det var vist nok industrikartofler. De var store og runde. Midde havde sørget for at lægge nogle til side og plantet dem $\mathrm{i}$ haven, hvor de fik en lidt bedre behandling. Også omkring første august fik vi nye kartofler på bordet. Det var vel nok en festdag. Folk, som ikke har prøvet det at undvære kartofler så længe, kan slet ikke tænke sig, hvilken lækkerbisken det er efter så lang tid igen at nyde en simpel kartoffel.

De fleste mænd i kommunen mellem 20 og 30 år var nu indkaldt, så der var så småt mangel på arbejdskraft. De bedste heste blev også indtrukket. Vi skulle nu også aflevere halm. Jeg kørte to læs til Flensborg. Ovre i Jørgensby var der en hel fabrik, der ikke lavede andet end at skære hakkelse. Der lå store lagre af halm og tagrør udenfor. På mit spørgsmål om hvad de brugte tagrør til, svarede han, at hakkelse af halm blev blandet med hakkelse af tagrør. Jeg havde ondt af de stakkels heste i Flensborg. Så havde vores heste det betydeligt bedre. De led i det hele taget ingen savn - endnu da.

Igen gik vi en mørk og kold vinter i møde, næsten uden nogen belysning. I hjemmene sad man rundt om et »Hindenburg-lys«. Det var en lille dåse med et eller andet brændbart i. Ud af låget stak der en væge, og når man tændte den, gav den næsten lige så meget lys som en fakkel. 
Hvert år op mod jul blev der iværksat store indsamlinger af »Liebesgaben « til frontsoldaterne. De første år havde også givet store resultater, men efterhånden var der jo ikke noget at samle ind. Og dog gjorde enhver familie sig de største anstrengelser for at glæde deres pårørende derude. Om det så kun blev til cigaretter, tobak, måske en ny pibe, et par enkelte hjemmebagte pebernødder eller et stykke sirupskage - en feltpostpakke skulle de have fra deres hjem.

\section{Den hårde, lange vinter 1916-1917}

1916-17 var en meget hård og lang vinter - ikke så meget med sne, men med hård frost. Den satte allerede ind en halv snes dage før jul. Og i hele julen kunne vi løbe på skøjter på Møllesøen; men ikke kun i julen. Hver søndag indtil påske, påskedagene indbefattet, løb vi på søen. Der var meget leben dernede. Fra Kobbermøllen kom de unge også. Der var nu også problemer med at løbe på skøjter. De fleste af dem var jo af den billige slags. Sålen blev klemt fast af en skrue, der var en vinkel på spændestykket på hver side af sålen. Den havde små takker, som bed sig fast $i$ sålen. Ved hælen var der en kappe, der foroven endte $i$ to spidser, som man skruede ind i hælen. Egentlig var de beregnet til også at spændes fast med remme, men remme var der ikke til at få. Så spændte man først fast om sålen, og derefter skruede man de to spidser på kappen fast ind i støvlehælen, så fast at det gav et knæk $\mathrm{i}$ hælen. Når man så tog et par skridt på skøjterne, så brækkede hælen af, og der blev ingen skøjteløbning mere den dag. Nå, så humpede man hjem med den afbrækkede hæl, fandt træskoene frem, opsnusede en slæde og to pigstager, og så fornøjede man sig med at stage sig frem $i$ voldsom fart, fra den ene ende af søen til den anden. Det var da også dejligt.

En gang imellem kom Kommerzienratens børn fra Krusågård med deres gæster ned på søen. De havde fået undervisning i skøjteløb og viste nu deres kunnen uden dog at blande sig med os. Vi stod måbende og så på, når de udførte ottetaller både på det ene og det andet ben, både forlæns og baglæns og mange andre figurer. Men de havde jo også det bedste, der fandtes i skøjter.

Den hårde, lange vinter satte os langt tilbage med forårsarbejdet, så vi fik meget travlt, da det endelig efter påske blev tøvejr. Al forårssæd kom jo for sent $\mathrm{i}$ jorden, og det gjorde sig bemærket senere $\mathrm{i}$ høsten. Men vi gjorde altså, hvad vi kunne, og vi var knap nok fær- 


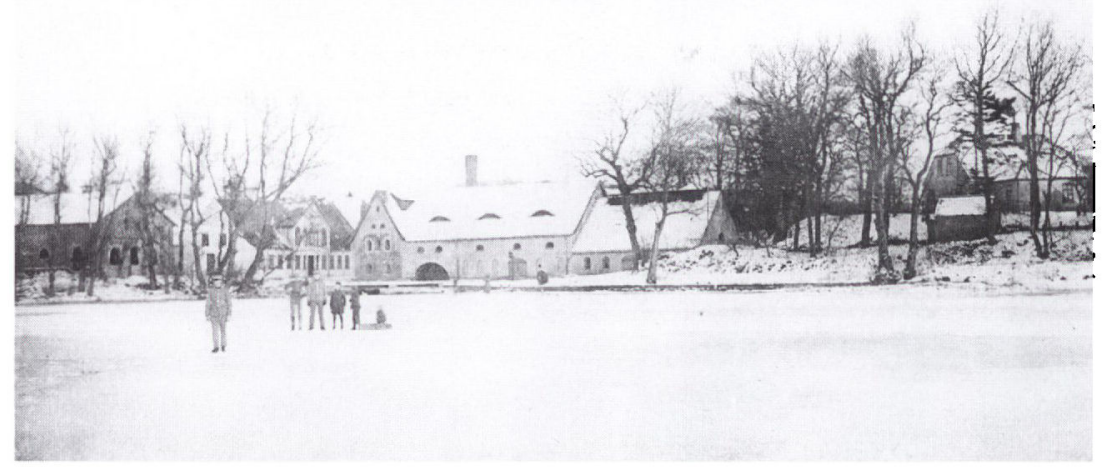

Vinterfotografi fra mollesøen. 1920. Vinteren 1916-17 kunne man løbe på skøjter på søen helt frem til påske. Foto: Bov Lokalarkiv.

dige med såningen, så trængte høhøsten sig på, og den var lige så stor som sædvanlig. Vi måtte ofte strække dagene.

\section{Messing-eventyret}

I foråret lagde man et feltbanespor fra Kobbermølle op til Smedeby Station. På det skulle smeltemateriale køres til fabrikken, hvor man smeltede det og lavede granattændere af det. Jes Asmussen var igen begyndt på Kobbermølle, og med et par heste kørte han skinnemateriale. Senere, da de begyndte transporten, blev han der også og kørte tipvognene med hestene, når det gik op ad bakken, medens en anden mand fungerede som bremse, når det gik nedad. Snart kom de første vognladninger materiale. Det kom fra Belgien, hvor man havde beslaglagt alt kobber- og messingtøj. Herhjemme havde vi for længst afleveret disse ting, men det var ret begrænset, hvad man her på egnen havde af disse sager.

I Belgien var det åbenbart anderledes. Børnene fortalte os om aftenen om alle de fine ting på tipvognene, som var blevet kørt gennem byen. De var helt ophidsede over alle de fine sager, de havde set. Efter fyraften gik vi så en tur op til stationen. Der stod fem tipvogne, som var læsset og færdige til transport næste morgen. Vi var mere end forundret over alle de ting, der var i vognene. Der var lysestager i alle størrelser, fra små sirlige på ti cm op til store svære på en meter, Kristus-figurer i samme størrelsesorden, der var små og større morte- 


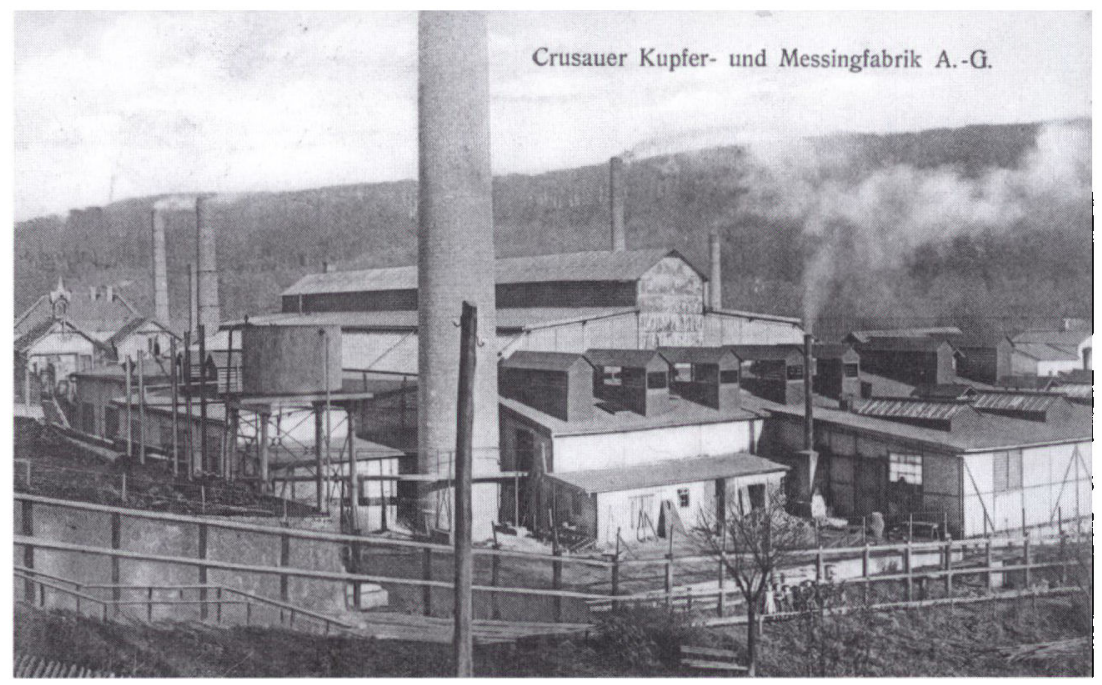

Kobbermøllen. Postkort fra 1920'erne. Foråret 1917 blev der anlagt et feltbanespor til Kobbermølle, hoorpd smeltemateriale skulle transporteres $i$ vogne til fabrikken. Men undertiden fandt Arnold Johannsen og de andre unge $i$ Smedeby værdifuldt messingtøj i vognene på sporet! Foto: Arkivet ved Dansk Centralbibliotek for Sydslesvig.

re og stødere dertil, kobberkedler, vægtlodder, statuer og statuetter, klokker, skåle, dørplader, men det er helt umuligt at nævne alle disse ting her. Der var vist tusinder af forskellige ting. En meget stor part af dem kendte vi overhovedet ikke, og vidste ikke, hvad de skulle bruges til. Der var mange ting, som var hentet lige ud af forretningerne, prisen hang endnu på dem. En stor del var hentet ud af kirkerne, blandt disse var der mange store tunge figurer. Når vi fik øje på en lille fiks ting, puttede vi den i lommen, for kort efter at falde over én, som vi syntes bedre om. Så kasserede vi den forste. Det blev ved i tre uger, og vi gik tro derop hver aften. Så holdt det pludselig op, og nu var det kun messingaffald, der kom. Det skete dog et par gange senere, at der kom sådanne brugsgenstande igen, og så var vi altid trofast på gåtur om aftenen. Vi stjal ikke ligefrem for vindings skyld, men vi lod dog gerne en lille ting, som vi syntes godt om, gå med. Det kunne være en lille fiks morter, som man så ofte skulle søge længe efter en passende støder til. Det kunne være en lille figur af en håndværker eller en landmand. Jeg har haft seks til syv styk, men de er for længst borte. Nogle har jeg foræret væk, andre har man franarret 
mig. Jeg beholdt ingen af dem længe. Men vi så egentlig ikke noget forkert $i$ at redde disse småting fra at blive smeltet om.

Engang var der løbet et par vogne af sporet og væltet nede ved slottet. De var begge læsset med små krucifikser af messing. Korset var indlagt med ibenholt, og derpå hang så en kristusfigur. De var meget smukke, og da de russiske fanger kom forbi, puttede de alle en håndfuld $i$ lommen, så de havde til deres kammerater også. De blev så hængt op over deres seng. Det var ganske vist ikke det kors, de brugte i Rusland, sagde Mitri, men i krigstid så Vorherre vist ikke så nøje på sådanne småting. Jeg vil dog tilstå, at vi også en gang imellem puttede nogle vægtlodder i lommen, som vi så senere afleverede hos Ulrich i Bov. Vægtlodder og dørgreb fik man særpris for, men det blev dog kun til småpenge. Så meget om messing-eventyret. I øvrigt havde de en vogn stående deroppe uden tippelad. Den lånte vi sommetider om aftenen og foretog halsbrækkende køreture ned ad bakken med.

\section{På session}

I februar 1917 var jeg 17 år og skulle til session i marts måned. Det foregik i Hotel Nordischer Hof, det nuværende Flensborghus. Vi blev opstillet ude $\mathrm{i}$ gården, og en underofficer råbte navnene op, som vi højt og tydeligt skulle besvare med: "Her!«. Så råbte han pludselig: "Johannsen, Jørgen ". Jeg agtede ikke der på, og der var ingen andre, der svarede. Han trak vejret dybt, og så kom det brølende igen: "Johannsen, Jørgen «. Så blev jeg vågen. Jeg havde, som så mange andre, to fornavne: Jørgen og Arnold. Dette Jørgen blev dog aldrig brugt, men underofficeren brugte det altså. "Her!«, råbte jeg af mine lungers fulde kraft. Han så meget bøs ud, men så brød han løs: "Står denne mors dreng ikke der og holder hele felttoget op ved at sove under andagten? Bare jeg kunne få ham 14 dage under behandling, så ville han vide, hvornår man skulle være vågen, og hvornår man ikke måtte sove!«. Jeg var vel egentlig sluppet billigt. Ved undersøgelsen fik jeg udsættelse et år. Vi var kun 4-5 stykker, der foreløbigt slap fri. Jeg var kun lille og spinkel, jeg var i det hele taget meget langsom i opvæksten. Jeg kan ikke huske, om jeg var glad eller ked af afgørelsen. Jeg længtes jo ikke efter fronten, men jeg ville lige så gerne være soldat som alle de andre, der nu sad inde $i$ restaurationerne og sang 


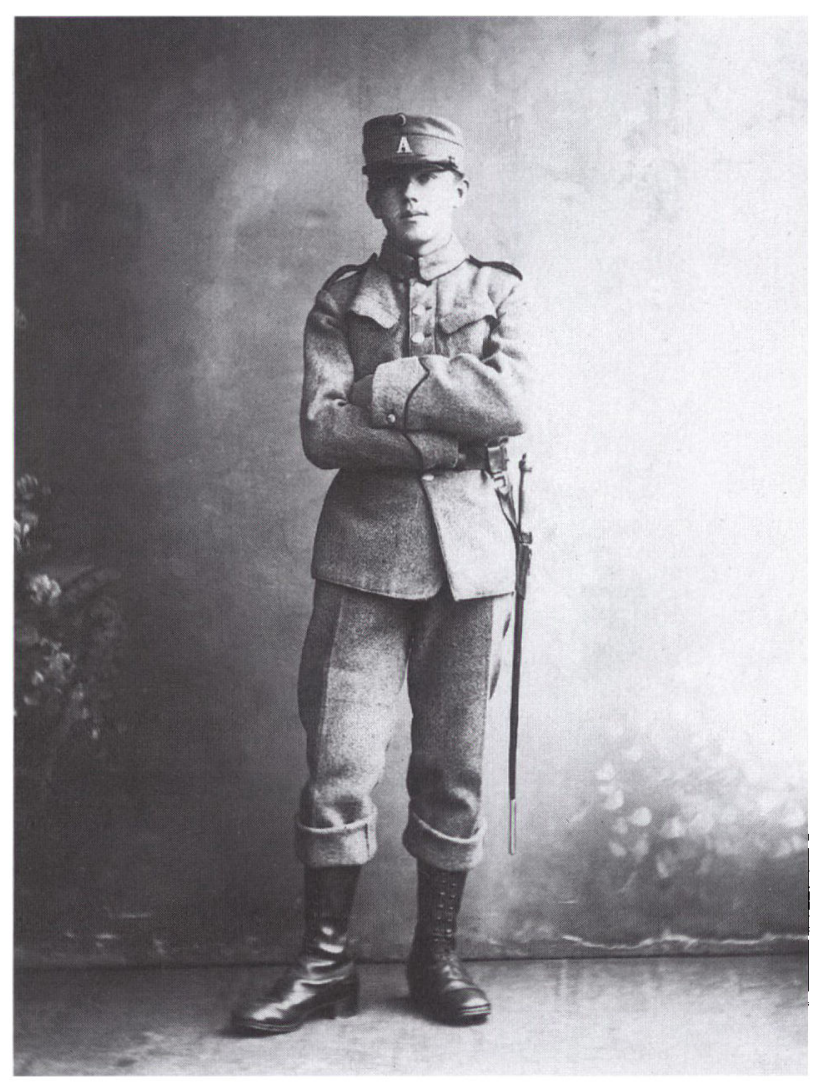

Arnold Johannsen

blev omsider soldat i 1922: dansk

arbejdssoldat ved

hjxipetropperne.

Foto: Chr. Johann-

sen og Else Ebjerg.

om »Stolzen Fels am Rhein«. De lykønskede mig og sagde, at jeg vel nok var en heldig kartoffel, men de mente det slet ikke.

I foråret 1918 skulle jeg igen til undersøgelse på JunkerhohlwegKaserne. Der var ingen andre end lægen og mig. Jeg kendte straks lægen igen. Det var Oberstabsarzt Schumacher fra Broager, som havde ligget $i$ kvarter hos os ved krigens udbrud. Men han havde selvfølgelig ikke lagt mærke til mig. Han kom til den mening, at jeg havde gjort fremskridt; men jeg måtte hellere få yderligere seks måneders frist. Egentlig var jeg vist ked af det. Det var jo sådan dengang, at en mand, der ikke havde været soldat, ham hæftede der altid noget mindreværdigt ved. Efter Genforeningen skulle jeg endnu en gang til session, denne gang hos det danske militær. Og det var mig en stor tilfredsstillelse, at jeg blev udtaget til infanteriet. Otte dage senere fik jeg meddelelse om, at jeg havde trukket frinummer - så brast den 


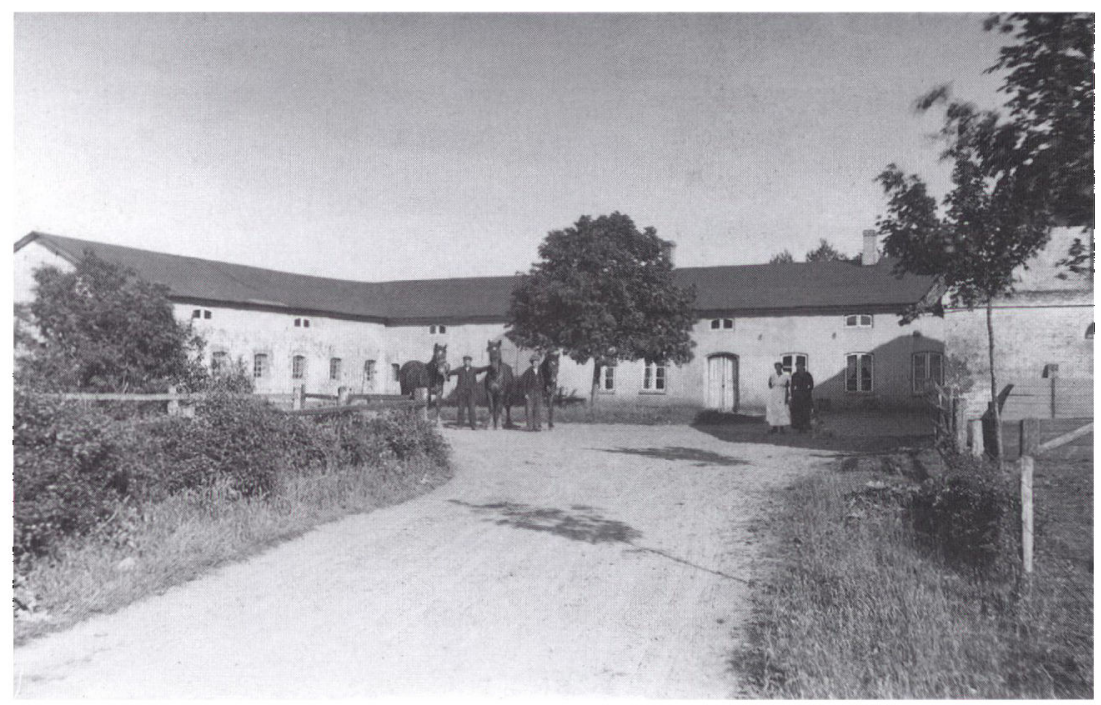

Chr. Lengers ejendom i Smedeby. Chr. Lenger blev meget hårdt såret $i$ krigen og kom sig aldrig helt over den härde medfart. Men med lejet arbejdskraft og Lengers dygtige styring lykkedes det at fă gården bragt tilbage $i$ sit gamle leje igen. Ca. 1916. Foto: Bov Lokalarkiv.

drøm. Atter otte dage senere kom der meddelelse om, at der skulle indkaldes 400 mand fra Sønderjylland til hjælpetropperne, og blandt dem var også jeg. Der var besked om, hvor og hvornår jeg skulle møde. Og den sommer var jeg så arbejdssoldat. Det var jo ikke noget elitekorps, men immerhen - jeg havde dog været soldat.

Men tilbage til 1917. Christian Lenger kom hjem. Han var blevet meget hårdt såret og lå $\mathrm{i}$ lang tid på lazarettet. Men nu havde de fået ham så vidt sammenflikket, at han kunne hjemsendes. Naturligvis var han faldet meget af, og han led vel også endnu under eftervirkningerne af den frygtelige medfart, han havde fået. Men han kunne dog godt gå rundt $\mathrm{i}$ byen og underholde sig med gamle bekendte. Det mindede om gamle dage, når han igen gik rundt med den halvlange pibe. Sit gode humør og snakkesalighed havde han endnu $i$ behold. Han lejede en dygtig karl, og så holdt de to piger, og under hans styre varede det ikke længe, før gården igen lå i sit gamle leje. Men fysisk var han ikke mere den samme. Han havde ikke mere de samme kræfter som før. Han blev ikke ret gammel. Han døde vist omkring 1935. Men han havde dog endnu haft nogle gode år sammen med Marie, hans kone. 
Karl Smed, smedens søn, blev også indkaldt. Og efter en meget kort uddannelse blev hans deling sendt til vestfronten. Karl ville gerne være soldat og også gerne gøre en indsats ved fronten. Det blev nu ikke til ret meget, for en halv snes dage senere var han allerede død og begravet. Karl havde været en meget god ven for mig, og jeg var dybt bedrøvet. Værre var det dog for hans forældre. De havde sat store forhåbninger til ham, som med et slag var tilintetgjorte. Især hans mor havde meget svært ved at komme over det.

Min bedstefar, mors far, boede nede på »Slottet« (se side 60), og mor gik hver dag ned og syltede og kogte lidt for ham. En dag hun kom derned, var han helt ude af sig selv. Han havde fået et brev fra admiralitetet. Han var ikke så bevandret i det tyske, og mor læste brevet for ham. De skrev, at ubåden, som Kisse, min fætter, gjorde tjeneste på, havde overskredet tiden, hvor den skulle være tilbage, med flere uger. $\mathrm{Og}$ da de intet havde hørt fra den, måtte de antage, at bådens tapre besætning, deriblandt Kisse, var gået under og havde fundet heltedøden for Tysklands ære. Bedstefar var helt slået ud. Kisse havde været hans ét og alt. Kisse var forældreløs. Indtil han var en halv snes år, levede hans mor endnu, og de boede hos mine bedsteforældre. Da bedstemoderen også døde, huserede de to alene. Kisse sørgede for madlavningen, hvilket han var dygtig til. Efter konfirmationen kom han i maskinbyggerlære, og ikke længe efter brød krigen ud. Kisse kom til marinen og meldte sig til ubådsstyrken. Før hans første togt havde han en kort orlov og var hjemme for at tage afsked. Jeg var ikke hjemme, da han besøgte os og gik derfor ned på "Slottet« for at tage afsked. Kisse havde altid stået som et forbillede for mig. Da jeg kom ind i den lille stue, stod de to overfor hinanden, begge meget alvorlige. Bedstefar lagde et par gange hånden på Kisses pande, og af og til slog han kors over dennes bryst, alt imens han fremsagde et længere ritual. Det varede lidt, før det gik op for mig, at det var det, man kaldte velsignelse, som man dog næppe brugte mere dengang. Efter at have endt ceremonien tog de afsked med hinanden, og jeg tog også afsked med Kisse og onskede ham altid god fart. Derpå gik Kisse op til stationen. Han havde været på adskillige farter, og hver gang han var i havn, skrev han. Men nu skulle han altså være borte. Bedstefar græd og klagede ustandselig, men det ændrede jo ikke noget.

Sent på efteråret var jeg beskæftiget oppe i Jacobslyken. Pludselig så jeg bedstefar komme humpende op ad markvejen. Jeg blev urolig - 
hvad kunne der nu være hændt, siden han, der havde så svært ved at gå, kom herop. Jeg løb hen til hegnet for at spare ham for noget af vejen. Da han kom nærmere, så jeg, at tårerne løb ham ned ad kinderne. Fuld af bange anelser spurgte jeg ham, hvad der var i vejen. Han kunne dårligt tale, så bevæget var han. Meget usammenhængende fik jeg at vide, at der var kommet et brev fra Rode Kors med meddelelse om, at Kisse var i live og befandt sig $i$ en engelsk fangelejr, og at han om kort tid ville få lejlighed til selv at skrive hjem. Jeg var lidt i vildrede, fordi bedstefar græd sådan, og mente at han ikke skulle græde. Når krigen var forbi, ville Kisse jo komme hjem igen. "Det er af glæde, min dreng, det er af lutter glæde, jeg græder. Jeg kan næsten ikke bære al denne glæde alene«. Jeg var også glad både på Kisses og bedstefars vegne. Bedstefar ville nok få lettere ved at bære denne glæde, end den sorg budskabet fra admiralitetet havde bragt ham. Nogle måneder senere kom der også brev fra Kisse. Han skrev ikke meget, men de havde det dog forholdsvis godt, og han havde jo nu berettiget håb om at komme hjem igen. Krigen var for ham til ende.

\section{Tilslutning til kraftværket}

Den største begivenhed i sommeren 1917 var dog tilslutningen af Smedeby til kraftværket i Flensborg, som skulle være tilendebragt inden vinterens komme. Allerede $\mathrm{i}$ juli så vi masterne på vej fra Bov til Smedeby. En mast for hver dag - men mere kunne det vel heller ikke blive til. De var fem mand om det, og til hver af de store lange master skulle der graves et meget dybt hul, og der var meget forskellig jord at arbejde i. Masterne måtte ikke stå for dybt og heller ikke rage højere op end et vist metermål, og så skulle de stå lige og vandret. Det var nok et hestearbejde at rejse de lange svære master, for alt foregik jo med håndkraft dengang. Men de nærmede sig langsomt dag for dag. I september kom der mere fart over feltet. Et par mandfolk begyndte bygningen af en transformator nede ved Pebergade tæt ved vores hestestald, og den lille bygning skød hurtigt i vejret. Så kom elektrikerne for at ordne installationerne. De begyndte ved stuehuset, hvor de blev færdig i løbet af en uges tid. Der var en udlært elektriker, Kirchenbauer, han var sydafrikaner og skulle ikke være soldat. Han var vist meget dygtig. Så var der lærlingen, der hed Kunze. Han gik mest og snusede rundt efter noget spiseligt. De skulle have kosten hos os, men Kunze sagde rent ud, at kosten hos os var 
meget miserabel. Han mente, der absolut måtte findes et sted, hvor de røgede pølser, skinker og flæskesider blev opbevaret. Vi så jo aldrig noget til disse ting, efter de var kommet hjem fra rogeriet, men mente dog, at de sandsynligvis lå $\mathrm{i}$ det store aflåste skab, der stod til højre i spisekammeret. Det havde han opdaget. Han havde to gange stået $\mathrm{i}$ dybe tanker foran skabet, mens de arbejdede $\mathrm{i}$ huset, og begge gange var husholdersken dukket op og havde forklaret ham, at de absolut ikke trængte til lys i selve skabet. Da Kunze ikke mente, at han kunne klare sig med den kost, vi fik, gik han hver aften, når pigen begyndte at malke, ud i stalden og tyllede al den mælk i sig, han kunne. Han skulle også gerne have noget med hjem om aftenen om ikke andet så et par kartofler, lidt rug og et par æbler og pærer.

Så snart de var færdige inde i huset, gik de i gang i staldbygningen. Det gik egentlig hurtigt. De befæstigede to rækker små isolatorer ved væggen. På dem viklede de på den ene række en rod og på den anden en sort isoleret tråd. Ikke noget med som nu til dags, at ledningen skulle være beskyttet af et rør.

I kostalden blev der afsat to lampesteder, et ved hver side, og et $\mathrm{i}$ hestestalden. De øvrige små rum fik også et lampested, og i loen blev der anbragt en lampe helt oppe under taget. I løbet af godt en halv snes dage var de færdige og flyttede til den næste gård.

Det var dog kun landbruget, der fik strøm. Det var vist hovedsagelig for tærskningens skyld, det hele blev anlagt. De mange små selskaber, der ejede tærskeværker, havde alle benzolmotorer, og benzol fandtes ikke mere. Når jeg nævnte, at elektrikerne var færdige hos os, så er det ikke helt korrekt. Ude i staldbygningen var der endnu ingen afbrydere, og det ville nok vare noget, inden den slags afbrydere kunne fås. Men Kirchenbauer vidste råd. Han skrællede et par ender isolering af de to tråde, der skulle forbindes med de kommende afbrydere, bøjede de afskrællede tråde om til hager, og når vi så hagede dem sammen, skulle der være lys. Det var der også, viste det sig senere. Der var bare den ulempe ved det, at når man om aftenen $\mathrm{i}$ mørke famlede efter de to ender, kunne man godt risikere at berøre den strømførende ende, og det gav en ubehagelig overraskelse. På den anden side - så blev man jo med ét lysvågen.

Anlægsarbejdet gik rask frem. De svære højspændingsledninger blev udrullet, isolatorer påsat masterne. De nødvendige apparater til transformatoren blev indsat, og først i oktober var det så vidt, at vi på Martins gård kunne tænde den ny belysning. På de andre gårde 
var de længe færdig med installationen. Det var et stort øjeblik, da Kirchenbauer trykkede på afbryderne. Han kontrollerede først beboelseshuset, det ene rum efter det andet. Alt var i orden. Derinde havde de afbrydere $i$ hvert rum. Ledningerne var også indlagt $i$ tynde rør, og ikke, som i udbygningerne, bare trukket på ruller langs væggen. Efter at have kontrolleret beboelseshuset kom han ud i staldbygningen. Han hagede de to ledningsender sammen, der gjorde det ud for afbryder, og straks brændte lampen. Den sad højt oppe under taget og strålede sit skarpe lys ud over hele det lange loft - fra den ene ende til den anden - undtagen de steder, hvor det ikke kunne komme til for hø- og foderbunker. Vi tabte helt mælet af lutter forundring. Det var mere, end vi kunne begribe, dette med elektricitet. Men efterhånden gik vores stumme forundring over til vild begejstring. Det var jo ganske vist menneskeværk, men dog følte vi det som et stort under. Alle rum blev afprøvet, og alt var tilfredsstillende. Forbi var det med denne famlen rundt $i$ mørke om morgenen og om aftenen, forbi med genstridige karbid- og spritlamper, ja selv i karlekammeret havde vi ikke brug for det lille beskedne "Hindenburg-lys«. Man glædede sig ligefrem til at komme i gang næste morgen med staldarbejdet $\mathrm{i}$ dette lysorgie. Det viste sig da også, at arbejdet om morgenen nu kun tog den halve tid, og så var det endda bedre udført. Naturligvis blev vi ikke ved med at gå rundt og være begejstret, men vi blev dog ved med at have glæde af forandringen.

\section{"Treffpunkt $« \mathrm{i}$ hestestalden}

Hestestalden havde altid været "Treffpunkt " for de unge om aftenen, når den mørke tid kom. Der var lunt, og den ene ende var pakket med rughalm, som vi bundtede sammen og sad på. Så sad vi der og underholdt os, det bedste vi kunne. Også her var det dejligt at have lys. Vi kunne spille kort, vise hinanden vore små nyerhvervelser, kunne en gang imellem øve os lidt $\mathrm{i}$ dansetrin - ja, der var så meget, vi kunne få tiden til at gå med. Ganske vist havde Martin indskærpet os at spare på lyset, men så længe hestene skulle affodres, skulle vi da bruge lys. Og desuden skulle Martin jo af sted klokken otte til Bov til lejren, hvor han skulle være om natten. Han kunne således ikke få ondt af, når vi brugte lys.

Høsten var besværlig det år. Vejret var så lunefuldt. Endnu midt i oktober gik vi oppe på skrænten ned til Majskoven og løsnede negene 
med blandfoder op og strøede dem lidt ud til den sparsomme solvarme og til vinden for at få dem til at tørre, for så bagefter at binde dem sammen igen og hurtigt få dem hjem. Kornet, der kom ind, var ikke alt sammen lige godt bjerget, men da vi siden i oktober fik tærsket, var Martin dog i det store og hele tilfreds med udbyttet. Til tærskeværket havde man nu fået en kraftig elektromotor i stedet for benzinmotor. For os var det ikke til nogen fordel, syntes vi. Den gamle benzolmotor lagde af og til en pause ind $i$ arbejdet, når den strejkede lidt. Så lå vi i halmen og hvilede os så længe, indtil den og smeden var blevet enige. Den nye derimod blev ufortrødent ved, fra klokken otte om morgenen til klokken tolv om middagen, og så igen fra klokken et til klokken fem. Det spillede faktisk heller ingen rolle, om det blev mørkt, for nu havde vi jo elektrisk lys.

\section{Kålrabi-vinteren 1917-1918}

Havde kornhøsten været vanskelig, så var roehøsten ualmindelig god. Den berygtede kålrabi-vinter 1917-1918 stod for døren, og især kålrabi havde vi usædvanlig mange af, langt ud over hvad vi selv havde brug for. Witt nede på gården ${ }^{2} \mathrm{i}$ Waldemarstoft, den der ligger nede $\mathrm{i}$ dalen, havde indrettet et tørreri for roer, og jeg kørte mange læs derned, hvor der blev lavet Dørrgemüse af dem. Det var jo næsten ved at blive Tysklands hovedernæring, især for småfolk $i$ byerne. $\mathrm{Nu}$ bagefter synes man, at det egentlig ikke er til at forstå, hvad folk kunne gå igennem dengang uden at murre. For noget som helst håb lå der ikke mere forude. Men de fandt sig i det, endda ikke helt uden humor. Således havde man lavet en ny del til katekismussens trosbekendelse, af hensyn til kålrabien. Den lød således:

Ich glaube an die Streckrübe

Die allgemeine Ernährung des deutschen Volkes

Gelitten unter dem Wucher der Bauern

Gesammelt, getrocknet und begraben

Und wieder auferstanden als Dürrgemüse

Von dannen sie kommen wird

Als Brotaufstrich für Deutschlands Heldensöhne.

2. Gården hedder nu Oldemoorstoft. 
Men ellers var det nu meget sløjt med humor. Det var mere usikkerhed og frygt for fremtiden, der greb folk, når aviserne søgte at berolige ved at henvise til alle de varer, vi kunne få fra Rusland, så snart forholdene dér faldt til ro. Men de faldt jo ikke til ro, tværtimod blev der stadig mere uroligt i Rusland.

Julen 1917 blev ikke bedre end det foregående år. Der blev pyntet lidt på den med sirupskager. Mange husholdninger havde plantet sukkerroer i deres haver, i begrænset antal selvfølgelig, og nu op til jul blev der kogt sirup af dem, og så bagte man småkager, hvis man kunne få fat $i$ lidt mel. Vi fik som sædvanlig langkål med svinehoved. Mitri var spændt på, om der igen gav en snaps til. Det gjorde der, men den var nu ikke som den russiske vodka. Vodka spillede i det hele taget en stor rolle i Mitris hukommelse. Også ved fronten havde de ofte fået vodka, især når de skulle angribe. Af den russiske vodka blev man uhyre $\mathrm{krepka}^{3}$ og længtes kun efter at gå i kast med tyskerne. Men der var alt for mange tyskere, og de blev næsten altid kastet tilbage.

Jeg fik en jakke til jul nede på gården. Den havde de syet af et af de mange hjemmevævede lagner, der lå i kister oppe på loftet. Den var ganske vist ikke meget bevendt til årstiden, og kuløren var heller ikke så praktisk, men jeg var dog glad for den. Mitri fik et par nye bukser. Det kom Martin nu billigt fra, for det var jo fangetøj, og det kostede ham ikke noget. Men Mitri glædede sig dog over dem.

Kort efter jul blev Christian, vores forkarl, indkaldt og kom til Rendsborg. Han besøgte os en gang, han var hjemme på lørdag-søndagsorlov. Det var sidste gang, vi så ham. Vi savnede ham meget. Han var en meget dygtig medarbejder og havde et meget omgængeligt væsen.

Også Theodor Lenger, der havde flere års krig i Rusland bag sig, var nu kommet til Frankrig og fandt døden der. Husholderskens bror, Hans, faldt også i Frankrig. Der var efterhånden faldet mange fra sognet, og der kom stadig nye til. Det var lige som om, det gik mest ud over de helt unge. Man sagde, at de ikke fik tid til at vænne sig til og tilpasse sig forholdene derude, inden de var borte. For der var jo adskillige, som havde været igennem det $i$ flere år og endnu ikke havde taget skade. Der var åbenbart også en del, der skulle læres.

3. Russisk udtryk, som betyder stærk. 
Vi fik arbejdet på gården gjort, også uden Christian. Der måtte så strækkes lidt på dagene. Vejrforholdene var ikke dårlige, og høsten var normal.

\section{Kapitulation og afmønstring}

Helt uventet dukkede der pludselig rygter op om strejker i Polen og om opstand blandt marinen. Man ville ikke tro, at sådan noget kunne ske i Tyskland. Men rygterne viste sig at være rigtige. I Kiel var der ligefrem revolution, og den bredte sig hurtigt og nåede også Berlin, hvor det kom til kamp. Også ud til fronten nåede uroen. Disciplinen faldt, og efterhånden gik der opløsning i det hele. I Smedeby så man med bange anelser på begivenhederne. Ville det gå som i Rusland? Man ville ikke tro det. Det tyske folk var et udpræget lovlydende samfund, der ikke nærede anarkistiske tilbøjeligheder. Men det ville ikke gå af uden svære brydninger, ja, de var der jo allerede. I Berlin kæmpede marinen mod infanteriet, og overalt søgte marinen at afvæbne og demoralisere tropperne. Der var ingen anden udvej end at søge våbenhvile. Den kom også i stand på de allieredes betingelser. Kejseren stak af til Holland. Der var vist ingen, der havde ventet sig andet af ham. Han havde i hele krigen ikke spillet nogen rolle.

Efter kapitulationen begyndte så afmønstringen af de mange soldater. De blev alle hjemsendt, undtagen et par af de yngste årgange. Et voldsomt trafikkaos begyndte. Mange lod sig slet ikke afmønstre først, men begyndte rejsen på egen hånd, som de gik og stod. Kun geværet lod de blive. De stormede togene, der gik i den rigtige retning. Ind imellem tog de en fodtur, indtil de fandt et andet brugeligt tog. Men hjem kom de alle efterhånden, den ene efter den anden. De, der blev afmønstret fik enten en grå uniform af den nye Litewka model, som ikke havde de mange knapper og andre militære indretninger, eller de fik et sæt gråt tøj i civilt snit, et enradet jakkesæt, der absolut ikke havde noget moderne anstrog. I hjemmene herskede der stor glæde. Krigens følger forsvandt ikke, men var da ligesom lidt lettere at bære for konerne. Der kunne godt være lidt problemer med børnene $\mathrm{i}$ første omgang. De 2-3 årige og 4 årige børn kendte jo egentlig slet ikke deres far. Han havde været hjemme på orlov et par dage om året, uden at de lærte hinanden at kende, og så snart han var rejst, var han også glemt. Nu gik han her i sit gamle civile kluns, og det så slet ikke ud til, at han ville rejse foreløbig. De havde lidt vanskeligt 


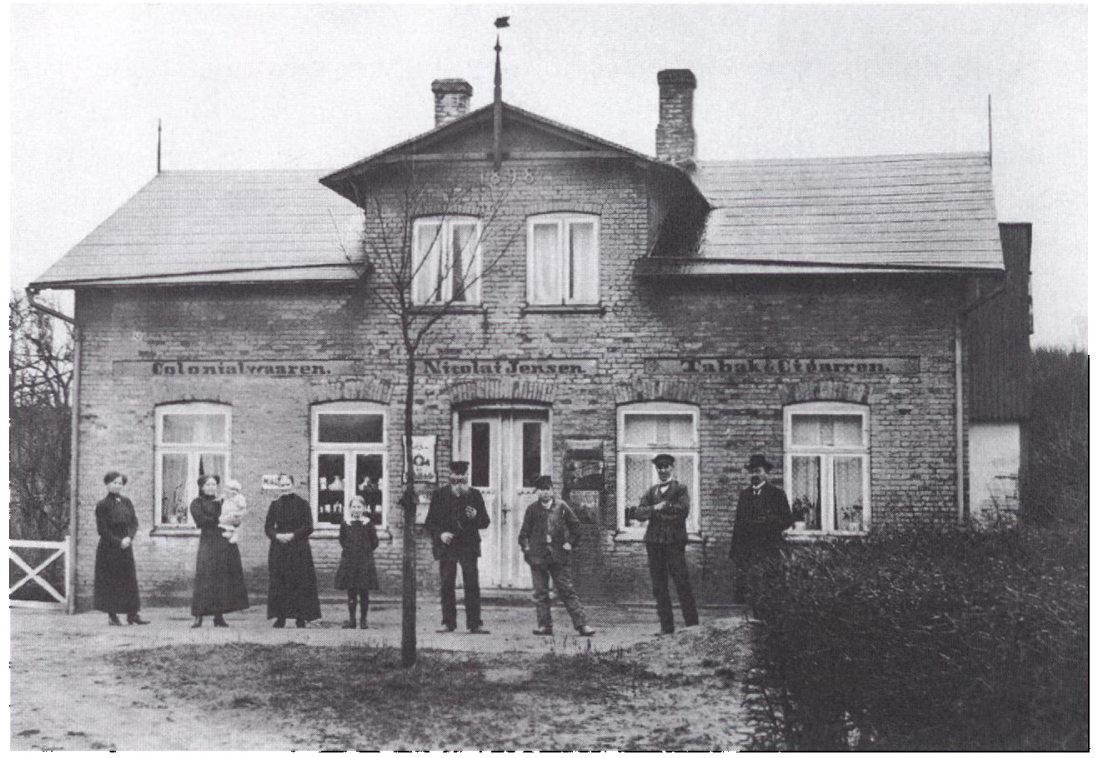

Middes kebmandshandel, som lå tæt på Martins gård i Smedeby. Ca. 1910. Foto: Bov Lokalarkiv.

ved at vænne sig til ham som et familiemedlem, der oven i købet gjorde krav på at være familiens overhoved. Men det jævnede sig dog hurtigt.

\section{Nye tider}

I byerne var der stor arbejdsløshed, men herhjemme var der arbejde nok. Kommerzienrat Hübsch på Krusågård, der ejede mange ejendomme her på egnen, beskæftigede flere hundrede mand ved anlægsarbejde og byggeri. Skovvæsenet indstillede også flere hundrede til brændefældning. Vejvæsenet brugte folk - jo, arbejde var der mere end nok af. Det kunne ofte være drøjt nok med en lang arbejdsvej, for cykel fandtes selvfølgelig ikke. Også levnedsmiddelforsyningen ændrede sig foreløbig ikke meget, men det blev da heller ikke værre. Alt $\mathrm{i}$ alt så man dog hen til lidt lysere tider, skønt man var forberedt på, at de endnu lå langt borte. Og så behøvede ingen mere at gå i stadig angst for sine pårørende ude ved fronten. Alene det var for mange det vigtigste.

De nye herrer indførte også nye skikke. Arbejdstiden blev fastsat 
til otte timer daglig. Vi ved landbruget mærkede nu intet dertil. Valgret gjaldt nu også for kvinder, og alderen blev nedsat til 18 år. Partierne fik frie tøjler, og der opstod et utal af dem, som alle lovede at føre Tyskland imod bedre tider, skønt ingen endnu røbede, hvilke uhyre erstatningskrav de allierede var ved at brygge sammen. Det viste sig senere at være $i$ så uhyre dimensioner, at ingen kunne fatte deres omfang. Den senere tyske regering bekendtgjorde dem derfor kun stykvis for ikke helt at tage modet fra folk. Der blev valgt en nationalforsamling, der skulle forsøge at bringe de mange partier under én hat og udarbejde en ny forfatning. Så skulle der vælges en ny rigsdag, en regering og en præsident. Det lykkedes også efterhănden at få dette arbejde gjort, og Tyskland havde nu en regering med et rekordantal partier - der var i hvert fald over 20 .

Forordningen om at heste ikke måtte slagtes, så længe de kunne støtte på benene, blev ophævet. Og dermed var vejen fri for gamle Lisas sidste gang. Hun var nu efterhånden helt opslidt. Hun var så træt, at hun om natten ofte lagde sig, og vi havde et forfærdeligt mas med at få hende på benene og få hende renset, men nu kom dog enden på hendes lidelser. Lisa var ikke en hest, man blev gode venner med. Hun var altid arrig over et eller andet og viste det tydeligt ved at vise sine store tænder frem, når man forsøgte at være god mod hende. Men hun havde dog i omtrent 20 år stået troligt på gården, havde givet os flere gode føl - skønt vi ikke fik megen glæde af dem, da flere af dem måtte med i krigen. Jeg var oprigtig ked af det, da hun drog af sted. Hun havde ikke fortjent en sådan ende at blive opslidt så at sige til sidste trevl og så blive ført til slagtegården. Men det var vel det bedste - arbejde kunne hun ikke mere.

De mange politiske partiers energiske propaganda smittede også af på beboerne i Smedeby. Folk, som før altid havde snakket udenom al politik, begyndte pludselig at få et politisk standpunkt, som de ivrigt søgte at påsnakke deres venner og bekendte. Og de stod helt uforstående, når man afviste bestræbelserne og fremholdt et andet parti som det eneste saliggørende. Man kunne godt blive lidt sur på hinanden, men det fortog sig dog ret hurtigt.

Der var også en anden mani, der greb folk. Under krigen havde der ikke måttet festes og danses. Nu var denne lov ophørt, og der opstod pludselig en trang til at indhente det forsømte hurtigst muligt. Overalt var der nu dans om søndagen. Også i Bov Kro, hvor der før krigen bare havde været bal 5-6 gange om året, var der nu dans hver 
søndag, og den var godt besøgt hver gang. Ved indgangen til salen hang der en stor plakat, der bekendtgjorde, at dans i jernbeslået fodtøj var forbudt, hvilket der vel ikke var noget at sige til. Kromanden stod ofte og lyttede opmærksomt ud over salen efter fordægtige lyde. Fik han fat $i$ en synder, trak han ham hen foran skiltet, og gav ham valget mellem at forlade salen eller at trække støvlerne af og danse i strømpesokker. De fleste valgte nu det sidste. Mange var nu på forhånd indstillet på at danse i strømpesokker og havde derfor et par overtrækssokker med. Stemningen var altid meget høj og alle aldersklasser fra 17-18 til 50 år deltog. De stærke drikke havde ikke rigtig fået indpas endnu. Man drak vin eller bowle, der også bestod af forskellige slags vine. Men rigtig berusede personer var dog sjældne. Ude i gæstestuen var stemningen som regel også ret høj. Her hengav man sig mere til politik, og det var vanskeligt at komme til en fællesnævner, da enhver havde sin ufejlbarlige mening. Enkelte havde endog to. Henimod foråret ebbede denne forlystelsessyge dog ud. Man havde vel indhentet det forsømte fra krigsårene.

I levnedsmiddelforsyningen skete der så godt som ingen forbedringer. Men ellers skete der dog lidt hist og her. Hver kommune fik sit arbejder- og bonderåd, valgt af folket, som det hed. Ved valget i Smedeby Kommune bestod folket, der strømmede til valg, kun af fire arbejdere. Det var Klaus, Jørgen Heel og min far. Den fjerde husker jeg ikke mere. De tilstedeværende blev enstemmigt valgt til arbejdernes medlemmer af rådet, idet de alle stemte på hinanden. På bondesiden var det straks lidt vanskeligere, fordi der ingen bønder var mødt. Men man enedes dog om at vælge Jørgen Lenger som formand for rådet og som repræsentant for bondestanden, skønt han slet ikke var der. Men han var jo dog den bedst egnede, fordi han var vant til at føre kommunens anliggender. Af protokollen fra et af disse møder fremgik det, at Jørgen Heel havde stillet forslag om at stille et ultimativt krav til arbejder- og soldaterrådet i Flensborg om omgående at forhøje smørrationen for Smedebys befolkning fra $50 \mathrm{~g}$ til $75 \mathrm{~g}$ om måneden. I modsat fald ville Smedeby spærre sine grænser for al aflevering til Flensborg. Men dette ultimatum blev dog ikke sendt ind til Flensborg, og rådet $\mathrm{i}$ Flensborg har nok aldrig fået at vide, hvilken frygtelig situation de derved havde undgået. 


\section{Afsked med fangerne}

Et par dage hen i januar, Mitri og jeg havde lige indfundet os til aftensmad, kom der to soldater ind $\mathrm{i}$ køkkenet. De var fra fangelejren, sagde de, og ville tale med Martin. Martin sad inde i sin stue og var i gang med sin eksklusive aftensmad. Siden revolutionen brød ud, havde ingen af deres foresatte ladet sig se. De var nok blevet afskediget, men der var nu ingen, der savnede dem.

Husholdersken, Midde, var lidt i vildrede med, hvad hun skulle gøre. Martin ville sikkert ikke have dem ind i sin private stue. Hun gik dog ind og anmeldte besøget. Martin kom ud, satte sig for bordenden og bød de to sidde ned på bænken. Han beordrede Midde til at stille et stykke brød og en tallerken hen til hver af dem. De to tog for sig af brødet og rugvællingen, og alt imens forklarede de Martin, at fangelejren i nær fremtid ville blive opløst. Martin var glad og overrasket og ville vide, hvornår det kunne ske. Det kunne de dog ikke sige noget om, men det ville sikkert ske indenfor en måned. Martin var glad. Så kunne han afmønstre og behøvede ikke mere haste til Bov for at være der om natten. Der ville komme en højere ansat, når det var så vidt, men vagtmanden skulle have listen over alt inventar, lager af fangetøj med mere klar til den tid. Så ville de få nærmere besked om afmønstringen. Den ene soldat henvendte sig til Mitri: »Bald nach Hause«, sagde han, »nach Shilata «. Jeg måtte oversætte: "Na domoi (hjem), 1 Monat. Virno? (virkelig?)«. Jeg stadfæstede det endnu en gang. Mitri, der ellers aldrig tabte fatningen, var synlig let rørt. »Na domoi, na Shilata«, sagde han lavmælt, og hans øjne fik et nærmest drømmende udtryk. Så fattede han sig hurtigt og kom i tanke om, at han endnu ikke havde takket Vorherre for aftensmaden. Hurtigt korsede han sig og fremsagde sin taksigelse. Han føjede en hel del til den, hvoraf jeg kunne forstå, at det var en tak for den gode nyhed. Skønt Mitri, efter sin egen mening, var en god bolschevik nu, afbrød han absolut ikke forbindelsen med Vorherre - man kunne jo aldrig vide. Soldaterne takkede for mad og tog afsked. Mitri havde også travlt nu, for han havde næsten ikke tid til at vente på Martin for at komme op i lejren og dele nyheden med kammeraterne. Det faldt ham svært at komme gennem måneden uden yderligere bekræftelse af meddelelsen, men Martin beroligede ham. Der var intet at tage fejl af. Vagtmændene havde jo også modtaget besked på, hvilke forholdsregler de skulle træffe. 
Pasfoto af Arnold Johannsen fra 1960'erne. Foto: Chr. Johannsen og Else Ebjerg.

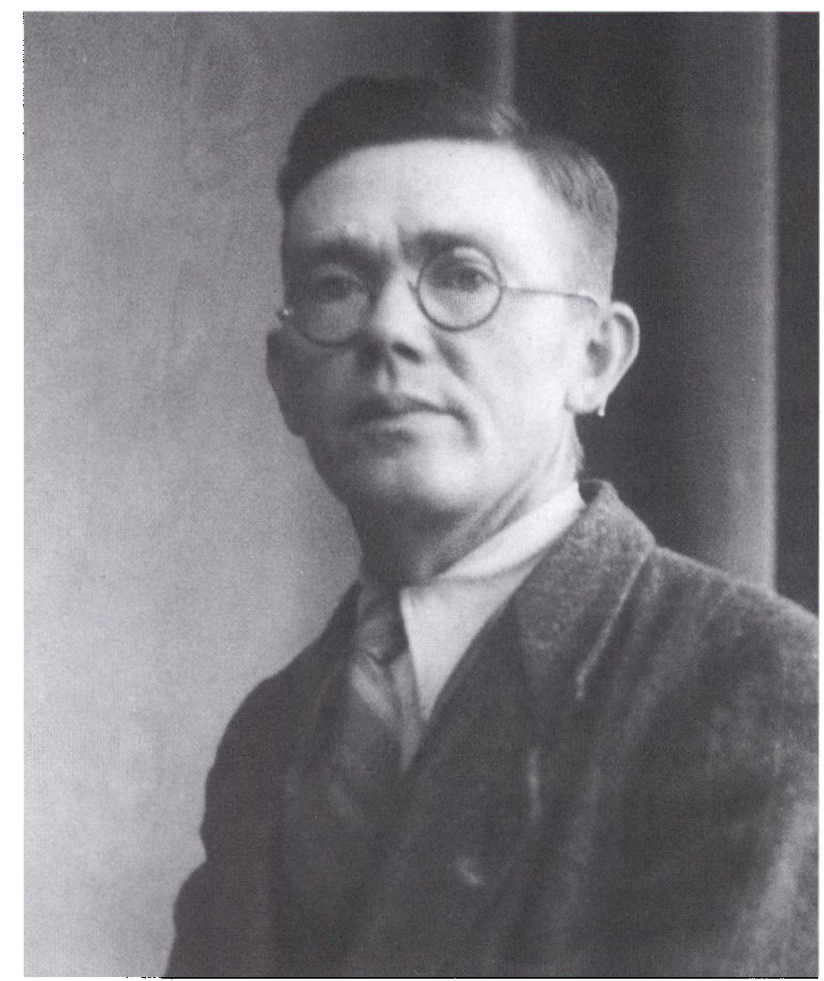

Og endelig - et par dage hen i februar, var det så vidt. Martin og Christian Jørgensen skulle transportere fangerne ud til banegården $i$ Flensborg, og efter afleveringen ville de blive afmønstret. Martin gik op til Bov og kom senere tilbage med otte fanger. De skulle køre med vort køretøj. Vognen blev tilrigget, så de kunne sidde ned. Martin ville køre med Christian Jørgensen, men jeg kunne godt køre forud, de ville nok snart være der. Jeg skulle bare køre op til Kieler-banegården og vente der, til de kom, men fangerne måtte ikke forlade vognen. Midde kom ud og overrakte Mitri en pakke. Jeg skønnede, at der var et halvt brød $\mathrm{i}$ den. De fleste andre fanger havde også fået lidt proviant med til rejsen. Vi kørte så. Fangerne var glade, og de sang næsten hele vejen, undtagen hvor der var stenbro. Jeg kørte ned langs havnen i Flensborg. Det var en diset dag, og der lå endnu snesjap på jorden. Jeg skammede mig ved at vise Flensborg frem - husene stod der uvenlige, grå og forsømte. Der var ikke meget liv ved havnen, og der lå da også kun et par mindre skibe, som ikke forsøgte 
at imponere nogen. Oppe ved banegården holdt et langt tog med lukkede godsvogne. I den forreste ende var man ved at kravle ind i dem. Langs resten af toget stod i lange rækker fanger opstillet med små mellemrum mellem hvert hold, og foran hvert hold stod vagtfolkene.

Jeg indskærpede fangerne, at de ikke måtte forlade vognen, og at de andre nok straks ville møde op. Det varede da heller ikke længe, før de kom. Martin gik hen foran ved toget, hvor der nok var en slags kontor, og kom tilbage med en soldat. Fangerne måtte nu stille op i to rækker for enden af de andre, og soldaterne begyndte et næsten langtrukkent arbejde med at læse deres navne op. Transporten fandtes $\mathrm{i}$ orden, og han gik hen $\mathrm{i}$ den forreste ende, hvor den åbenbart skulle godkendes. Jeg måtte godt køre hjem, sagde Martin, de skulle jo endnu havde deres afmønstring $\mathrm{i}$ orden. Ivan Stupiz rakte hånden ud for at sige mig farvel. Han var meget bevæget, gav mig hånden og sagde: "Auf Wiedersehen, jeg aldrig glemme Smedeby, folk i Smedeby så god ved stakkels Ruski«. Jeg sagde: "Auf Wiedersehen« skønt der nu absolut ingen chancer var for et gensyn - og vendte mig mod Mitri. Han trykkede min hånd: "Dosvedanje Arnold « - "Dosvedanje Mitri«. Dermed var vore veje skilt. Jeg ved ikke, om de er kommet velbeholdne hjem, men jeg onskede det af hele mit hjerte. Det blev sagt, at ved grænsen, hvor fangerne skulle overgives til Rød Front tropperne, indrullerede man dem uden videre i Røde Armé. Men der blev nu fortalt så meget om Rusland, det var vel ikke alt sandt. I hvert fald håbede jeg det bedste for vore fanger. Jeg kørte langsomt hjemad. Jeg blev helt nedtrykt undervejs. Livet på gården forekom mig pludseligt at være så ensformigt og trist, og jeg besluttede at rejse fra den. Der var jo nok andet arbejde. Til 1. april 1919 gjorde jeg alvor af tanken. Da havde jeg også tilbragt seks år på gården. 